BRIAN TAMANAHA:

HUKUK TEORILERININ “KAYIP KOLU” IŞIĞINDA

HUKUK KAVRAMINI YENIDEN DÜŞÜNMEK*

Dr. Öğretim Üyesi Nazlı Hilal DEMiR ${ }^{* *}$

öz

Henüz hukuk fakültelerinin ilk yıllarından itibaren karşılaşılan ve ilk etapta cevaplanmasının kolay olduğu düşünülen "hukuk nedir?" sorusunun literatürde tek bir yanıtının olmadığı bilinmektedir. Bunun nedenini, hukuk kavramının görünenden çok daha karmaşık bir arka planının bulunduğu şeklinde açıklamak mümkündür. Bu durumu destekler nitelikte Brian Tamanaha'nın, eserlerinde -günümüze kadar gelen hukuk tanımlarının neden başarısız olduklarına ilişkin tespitleri ışığında- söz konusu soruya net bir cevap geliştirebilmenin mümkün olmadığını ileri sürerek adından oldukça söz ettirdiği görülmektedir. Buradan hareketle çalışmada okuyucu, Tamanaha'nın görüşleri doğrultusunda mevcut hukuk tanımlarını sorgulamaya ve hukuk kavramını yeniden düşünmeye davet edilmektedir.

Anahtar Kelimeler: Brian Tamanaha, Hukuk Teorileri, Hukuk Kavramı, Gerçekçi Hukuk Teorisi, Toplumsal Hukuk Teorisi.

Yayın Kuruluna Ulaştığı Tarih: 30/03/2021

Kabul Edildiği Tarih: 11/05/2021

** İstanbul Kültür Üniversitesi, Hukuk Fakültesi, Hukuk Felsefesi ve Sosyolojisi Anabilim Dalı E-Mail: nh.demir@iku.edu.tr

ORCID: 0000-0002-2190-3749 
BRIAN TAMANAHA:

\title{
RE-THINKING THE CONCEPT OF LAW
}

\section{IN LIGHT OF THE LEGAL THEORIES' LOST BRANCH}

\begin{abstract}
It is known that there is not a single answer to the question of "what is law?", which has been encountered since the first years of law faculties and is thought to be easy to answer at first. It is possible to explain the reason for this as the concept of law has a much more complex background than it appears. In support of this situation, it is seen that Brian Tamanaha has made a name for himself by arguing that it is not possible to develop a definitive answer to the question, in the light of his arguments as to why the portrays of law have failed until today. In this context, the reader is invited to question the existing definitions of law and rethink the concept of law in line with Tamanaha's views.
\end{abstract}

Keywords: Brian Tamanaha, Legal Theories, Concept of Law, Realistic Theory of Law, Social Legal Theory. 


\section{GíRiş}

Tarih boyunca birçok teorisyenin, cevaplanmasına yönelik sayısız girişimleri bulunan "hukuk nedir?" sorusu karşısında verilen yanıtlarda üç baskın yaklaşımın rol oynadığından bahsedilebilmektedir. Birbirinden farklı bu bakış açılarının tümünün, günümüzden iki bin yıldan fazla bir süre önce kaleme alınan Minos diyaloğunda ortaya koyulduğunu görmek ise son derece heyecan verici niteliktedir. Bu doğrultuda Minos diyaloğuyla paralel olarak -zaman içerisinde farklı isimler alsalar da- literatürde hukuk teorilerinin üç temel kola ayrıldığı görülmekte, ancak günümüze yaklaşıldığında bu teorilerden birinin adeta sürgüne gönderilmiş olduğu anlaşılmaktadır. Bu durum karşısında hukukun doğasına ilişkin teorik tartışmalarda önemli bir perspektifin eksik kaldığına dikkat çeken Brian Tamanaha, bir yandan ortadan kaybolan üçüncü teoriyi ait olduğu yere koymaya çalışmakta, diğer yandan özellikle geri kalan iki akım çerçevesinde ileri sürülen biçimsel ve işlevsel hukuk tanımlamalarının başarısız bir görünüm sergilemekte olduklarını vurgulamaktadır. Peki, Tamanaha'ya göre bu savların ardında bulunan gerekçeler nelerdir ve dahası farklı bir hukuk tanımı mümkün müdür? İşte çalışma boyunca bu soruların cevaplarına odaklanılarak Minos-Kayıp Hukuk TeorisiBrian Tamanaha üçgenine ışık tutulmaya çalışılacaktır.

\section{MINOS YA DA YASA ÜZERINE}

Sokrates: Söyle bakalım, bizim için yasa nedir? Öğrenci: Hangi tür yasadan bahsediyorsun?

Sokrates: Bu da ne demek?

Bir yasayla bir diğer yasa arasında yasa olmaları açısından fark mı bulunuyor? Şimdi sana sorduğum şeyi bir düşün. Bunu sana "altın nedir?" diye sormuş gibi soruyorum. Bu durumda eğer bana ne tür bir altından bahsettiğimi sorsaydın, sanırım doğru bir soru sormuyor olurdun. Altının diğer altından ya da taşın bir diğer taştan, altın ya da taş olmaları açısından farkları bulunmadığını düşünüyorum; aynı şekilde yasa da diğer yasadan herhangi bir şekilde farklı değildir. Tüm yasalar aynıdır. Herhangi biri daha az ya da daha fazla yasa olmayıp, hepsi aynı derecede yasadır. Sorduğum şey tam olarak bu: Genel anlamda yasa nedir? $(313 a-b)^{1}$

Platon'un, adını Zeus'un oğlu (ve öğrencisi) olan Girit kralı Minos'tan alan² tartışmalı -belki de bu nedenle literatürde hak ettiğinden daha az önem verilen- Minos diyaloğu, Sokrates'in "yasa nedir?" sorusuyla başlamakta ve ardından yasanın doğasına ilişkin açıklamalarla devam etmektedir. Tarih boyunca birçok teorisyenin,

1 Çalışmada Minos diyaloğu kaleme alınırken üç farklı eserden yararlanılmıştır. Bununla beraber, gerekli görüldüğü yerlerde diyalog sadeleştirilerek aktarılmış ve akıcılığın sağlanabilmesi amacıyla çoğunlukla anlam odaklı çeviri yöntemi benimsenmiştir. Çeviride yararlanılan eserler için bknz. Thomas L. Pangle, The Roots of Political Philosophy: Ten Forgotten Socratic Dialogues, London, Cornell University Press, 1987, s. 53-66; Huntington Cairns, "What Is Law?" Washington and Lee Law Review, C:27, S:2, s.211222; W.R.M. Lamb, Plato: Charmides, Alcibiades 1 \& 2, Hipparchus, The Lovers, Theages, Minos, Epinomis, Cambridge, Harvard University Press, 1927, s.389-421. Ayrıca Minos diyaloğunun Türkçe çevirileri için bknz. Platon, Minos-Epinomis, (çev.) Furkan Akderin, İstanbul, Say Yayınları, 2020; Platon, Minos, (çev.) Hamdi Varoğlu, İstanbul, Sosyal Yayınları, 2001.

2 Üçüncü kişinin dahil olmadığı ve Sokrates dışında herhangi bir isme rastlanmayan bahse konu diyalog, bu nedenle adını genelin aksine bir konuşmacı ya da dinleyiciden değil; diyaloğun içerisinde kendisinden bahsedilmekte olan efsanevi kral Minos'tan almaktadır. 
cevaplanmasına yönelik sayısız girişimleri bulunan söz konusu soruyla başlayan bu diyaloğun Platon'a ait olduğuna ilişkin şüphe duymayan yazarlar ${ }^{3}$ olduğu gibi, diyaloğu Platon'un iyi bir taklidi olarak nitelendirenler ${ }^{4}$ de bulunmaktadır. Bununla beraber, Sokrates ile -belki bu zor soru karşısında dikkat dağıtmamak adına- ismi belirtilmeyen bir öğrenci arasında geçen diyaloğun, Platon'un (Sokrates'in adının hiç geçmediği) Yasalar eserine bir giriş niteliği taşıdığı da düşünülmektedir ${ }^{5}$. Minos diyaloğunun son bölümünde Tanrı Zeus'un oğlu Girit kralının yaptığı yasalar övülmekte iken, Yasalar eserine bahse konu yasaların incelenmesi ile giriş yapılmaktadır ${ }^{6}$. Kısacası, Minos'un bittiği yerde Yasalar başlamaktadır. Diğer yandan, yasanın ne olduğuna ilişkin soru ve cevaptan ibaret olan bu kısa diyaloğun Platon'un evrensel olarak kabul edilmiş diğer yazılarından hem üslup hem de içerik bakımından farklı nitelikler taşıdığı ileri sürülmektedir. Ancak bu çalışmanın girişinde Minos diyaloğunun kullanılmasının nedeninin Platon'da yasa kavramının incelenmesi olmadığı düşünüldüğünde, esere ilişkin literatürde yaşanan tartışmaların ${ }^{7}$ negatif etkisi ortadan kalkmakta; Minos'un Platon'un orijinal eseri olsun ya da olmasın- içinde barındırdığı görüşlerle, hukuk kuramı açısından sahip olduğu değer ortaya çıkmaktadır.

Bu doğrultuda, yazarına ve yazıldığı zamana ilişkin varlığını korumakta olan gizem, geçmişten bu yana hukukun kaynağına, tanımına, işlevine yönelik aralarında köklü tartışmaların mevcut bulunduğu hukuk akımları açısından diyaloğun önemini azaltmamakta, bu alanda önemli bir eser olduğu gerçeğini değiştirmemektedir. Nitekim Minos, Platon'un diyaloglarında "yasa nedir?" sorusunun spesifik şekilde sorulduğu ilk ve tek örnek olarak karşımıza çıkmaktadır ${ }^{8}$. Geçmişte ve günümüzde (ve muhtemelen gelecekte) birinin, bir diğerini kesin olarak çürütebilmesi ya da mutlak doğru kabul edilmesi mümkün olmayan farklı yaklaşımlar çerçevesinde cevaplandırılmaya çalışılan bu soru; temel amaçlarından biri hukukun doğasını ve işlevini açıklığa kavuşturmak olan hukuk kuramlarının kalbini oluşturmaktadır. Buradan hareketle, yasaların yasa olarak sahip olduğu; diğer deyişle yasa kavramının genel niteliğini keşfetmeye yönelik bu kapsamlı soru bir yana, bu sorunun devamında yer alan cevaplar ve Sokrates'in bu cevaplar karşısında ileri sürdüklerinin incelenmesi gerekmektedir.

Öncelikle Sokrates'in, diyaloğun ilk satırlarında soruya hazırlıksız yakalandığı anlaşılan ve soruyu tam olarak kavrayamayan öğrenciden -altın ve taşı kullanarak

3 Leo Strauss, Liberalism Ancient and Modern, University of Chicago Press, London, 1995; Bradley Lewis, "Plato's Minos: the Political and Philosophical Context of the Problem of Natural Right," The Review of Metaphysics C:60, S:1, 2006; William Cobb, "Plato's Minos," Ancient Philosophy, C:8 S:2, 1988.

4 Christopher Rowe, "Cleitophon and Minos," Cambridge History of Greek and Roman Political Thought, (ed.) Christopher Rowe ve Malcolm Schofield, Cambridge, Cambridge University Press, 2000; Anton Hermann Chroust, "Anonymous Treatise on Law: The Pseudo-Platonic Dialogue Minos," Notre Dame Law Review, C:23, 1947; A. E. Taylor, Plato: The Man and His Work, New York, Humanities Press, 1952.

5 Strauss, s.65; Chroust, s.47,48; Mark J Lutz, "The Minos and the Socratic Examination of Law," American Journal of Political Science, C:54, S:4, 2010, s. 990.

6 Plato, Laws (Book 1-6), (ed.) R.G. Bury, C:1, Cambridge, Harvard University Press, 1961, s. 3.

7 Bu tartışmaların kısa bir özeti için bknz. Lutz, s.990-993.

8 Claire McCusker, "Between Natural Law and Legal Positivism: Plato's Minos and the Nature of Law," Yale Journal of Law and the Humanities, C:22, S:1, 2010, s.83; Cairns, s.202. 
vermiş olduğu örnek göz önünde tutulduğunda- yasanın türlerine değil, genel anlamda yasa kavramına ilişkin bir tanım istemekte olduğu ortaya çıkmaktadır. Zira taşların türleri açısından aralarında farkılık oluşabilecekken; bir taş, taş olması açısından diğer taşlardan farklılık göstermeyecektir. Yasaların da yasa olmaları açısından birbirlerinden farkı olmadığını belirten Sokrates'e, bu örnek kapsamında öğrencinin verdiği ilk cevap şu şekilde karşımıza çıkmaktadır:

Öğrenci: Yasa, yasa olarak kabul edilen şeylerden başka ne olabilir? (313b)

Öğrencinin ilk cevabı, yasanın nereden geldiğini kimsenin bilmediği; "yapılmamış, fakat kendiliğinden oluşmuş" olduğu yönündeki düşünceleriyle tutarlı bir görünüm sergilemektedir ${ }^{9}$. Bu tanım doğrultusunda yasanın kökeni, örneğin yazılı kurallarla değil, vatandaşların kimi şeylerin yasa olduğuna ilişkin inançları ve bunlara riayet etmeleri ile açıklanabilmektedir. Farklı bir deyişle yasa, yalnızca bir grup insanın kendisini yasa olarak kabul etmesi nedeniyle yasadır. Böylece -diyaloğun farklı çevirilerini bir araya getirerek- öğrencinin bu cevapla beraber yasayı, toplumdaki yerleşik kurallar ve bağlayıcı gelenekler bütünü olarak değerlendirdiğini söylemek yanlış olmayacaktır ${ }^{10}$. Ancak bu cevaptan pek memnun olmayan Sokrates yasanın, yasa olarak kabul edilen şeylerden farklı bir niteliğe sahip olduğunu ortaya çıkartmak amacıyla durumu bir örnekle açıklayarak, öğrenciyi yeni bir yasa tanımı yapmaya davet etmektedir:

Sokrates: Peki sana göre, konuşma, konuşulan; görme, görülen ya da duyma, duyulan mıdır? Yoksa konuşma, konuşulandan; görme, görülenden; duyma, duyulandan ve bu doğrultuda yasa, yasa olarak kabul edilenlerden farklı bir şey midir?

Öğrenci: Evet, şu an yasanın farklı bir şey olduğunu düşünüyorum... (313c)

Sokrates: O halde yasa başka ne olabilir? Şimdi konuyu farklı şekilde ele alalım. Eğer biri gelip yukarıda konuştuklarımıza ilişkin bize 'şayet görülen, görme aracılığıla görülüyorsa, o halde görme nedir?' diye sorsa ona 'gözler aracılığılla nesneleri görmemizi sağlayan duyudur' şeklinde cevap verirdik...Peki aynı kişi bize şunu sorsa: 'Şayet yasa olarak kabul edilenler, yasa aracılığıyla yasa olarak kabul edilmekte iseler o halde, yasa nedir?'(314a)

Öğrenci: ...O halde, yasa devletin bir kararıdır.

Sokrates: Öyle görülüyor ki yasanın, devletin bir görüşü olduğunu söylüyorsun... Bu konuda haklı olabilirsin. Ancak belki şu şekilde daha iyi anlayabiliriz... (314c)

Diyaloğun bu aşamasında, öğrencinin yasanın tanımına ilişkin vermiş olduğu ikinci cevap karşısında Sokrates'in, yasanın devletin bir görüşü olduğunu noktasında kısmen öğrencisine katılmakta olduğu görülmekle beraber; bu görüşlerin içeriğinin de incelenmesinin gerekli olduğundan hareketle, bu tanıma getireceği eleştiri için çok fazla beklenmesi gerekmemektedir. Bu eleştiriyi getirirken Sokrates, aslında yasanın sahip olması gerektiğini düşündüğü önemli bir özelliğe dikkat çekmektedir:

Sokrates: ...Aynı zamanda yasanın kusursuz olduğunu kabul etmeli ve onu 'iyiler' arasında aramalıyı.

Biz biraz önce yasanın, devletin bir kararı olduğunu söylememiş miydik? ... (314d)

\footnotetext{
9 Strauss, s.67

10 Cairns, s.211.
} 
Ancak kararların hem iyi hem de kötü olanları vardır değil mi?

Öğrenci: Kesinlikle.

Sokrates: Ancak yasa kötü olamaz... O halde, yasayı yalnızca devletin bir kararı olarak tanımlamak yanlıştır.

Öğrenci: Öyle görünüyor.

Sokrates: Bu durumda kötü bir kararın yasa sayılması uygun olmaz. (314e)

Diyaloğun bu bölümüne ilişkin olarak iki görüşten bahsetmek gerekmektedir. Bunlardan ilki, yasayı salt devletin bir kararı olarak; diğeri ise yasayı iyi, kusursuz, adil gibi kimi niteliklerle beraber ele almaktadır. Bunların çatışması durumunda ise Sokrates'in, kötü kararların yasa sayılmasının uygun olmayacağı ifadesinden hareketle ikinci görüşe yakın bir duruş sergilemekte olduğu anlaşılmaktadır ${ }^{11}$.

Bu konuşmaların ardından, yasanın var olan şeyin keşfi olma iddiası taşıdığına ilişkin görüşlere uzanan diyaloğun, öğrencinin ileri sürdüğü önemli bir itirazla kesilmekte olduğu görülmektedir. Bu noktada yasanın, var olanın keşfi olma iddiası taşıması ile zorunlu olarak var olanın keşfi olması ifadeleri arasındaki farkı görmezden gelerek hataya düştüğü gözlemlenen öğrenciye göre yasa, var olanın bir keşfi ise her zaman ve her koşulda aynı olmak ve değişmez bir nitelik taşımak zorundadır. Buradan hareketle, zaman ve mekâna göre farklılık gösteren yasaların, yasa sayılması da mümkün görünmemektedir.

Öğrenci: Eğer yasa var olanın keşfi ise nasıl oluyor da aynı koşullarda her zaman aynı yasalar geçerli olmuyor?... (315a) Farklı toplulukların farklı yasalara sahip olduklarını ve aynı toplulukların mütemadiyen aynı yasaları kullanmadıklarını görmek zor değil. (315b)

$\mathrm{Bu}$ itirazdan hareketle Sokrates, öğrencinin değişmez nitelikteki yasa ile insanların yapmış oldukları kusurlu yasalar arasındaki farkı kavrayamadığını düşünmektedir. İtiraz karşısında öncelikle öğrenciyi haklı bularak tespitinin yanlış olmadığını belirten Sokrates, bu durumu destekleyecek şekilde farklı toplumlarda farklı yasaların varlığına ilişkin örnekleri çoğaltmaktadır. Ancak Sokrates'e göre bu durumun nedeni, yasanın var olanın keşfi olma iddiası taşımasında saklıdır. Yasanın her zaman bu iddiayı taşıyor olması, insan yapımı tüm yasaların zorunlu olarak var olanın birer keşfi oldukları şeklinde yorumlanmamalıdır. Yasaların topluluklara ve zamana göre farklılık göstermesi, kusurlu insanların var olanı, hakikati her zaman keşfedememesi ile açıklanabilmektedir. Diğer yandan, tamamıyla insanların kusurlarından, onların yetersizliklerinden kaynaklanan bu durum yasanın sahip olduğu nitelikleri etkilememektedir ${ }^{12}$.

Bu noktada, yukarıda kalın yazı tipi ile öne çıkarılan ifadeler ile Minos diyaloğunun -bu çalışma açısından isteneni verdiğinden hareketle- daha ayrıntılı şekilde incelenmesine gerek duyulmamaktadır. Bununla beraber diyaloğun, çalışma açısından nasıl bir öneme sahip olduğuna ya da çalışmanın başlığıyla nasıl doğrudan bir ilişki

$11 \mathrm{Bu}$ duruş ise akıllara "adaletsiz yasa, yasa değildir" ifadesinin gelmesine neden olmaktadır. Bu ifadenin pozitif hukuk açısından doğuracağı sonuçlara yönelik farklı bir değerlendirme için bknz. John Finnis, Natural Law and Natural Rights, Oxford, Oxford University Press, 2011, s.363-366.

12 Lutz, s.995. 
içerisinde bulunduğuna ilişkin soruları hemen cevaplamayarak, soru işaretleri ile bir sonraki başlığa geçmenin; Minos gibi zamanı ve yazarına ilişkin tartışmaların varlığını koruduğu bu gizemli diyaloğa yakışacağı düşünülmektedir.

\section{HUKUK TEORILERININ 'KAYIP KOLU'}

Hukuk, tarih boyunca çok farklı şekillerde tanımlanmış olsa da üç baskın yaklaşımın ön planda yer aldığından bahsedilebilmektedir. Buna göre, ilk yaklaşım hukuk ve ahlak arasındaki ilişkiye vurgu yapmakta; ikinci yaklaşım hukuk ve devlet arasındaki ilişkiyi ön plana çıkartmakta; son yaklaşım ise hukuk ve toplumun tarihsel gelişimi arasında bulunan ilişki üzerine yoğunlaşmaktadır ${ }^{13}$. Birbirinden farklı bu bakış açılarının tümünün, günümüzden iki bin yıldan fazla bir süre önce kaleme alınan Minos diyaloğunda ortaya koyulduğunu görmek ise son derece heyecan verici niteliktedir. Bu doğrultuda, bir önceki başlık altında Minos diyaloğunda geçen ve kalın harflerle belirtilen ifadeler ile hukukun tanımlanmasına ilişkin günümüze kadar süregelen bu yaklaşımlar arasında doğrudan bağlantı kurmak için tek yapılması gerekenin, bu yaklaşımlardaki sıralamayı değiştirmekten ibaret olduğu görülmektedir.

Buna göre, Minos'ta ilk olarak yasa, yerleşik kurallar ve bağlayıcı gelenekler bütünü olarak tanımlanmakta ve farklı toplulukların farklı yasalara sahip olduklarının ve aynı toplulukların mütemadiyen aynı yasaları kullanmadıklarının altı çizilerek yasa ile toplum arasındaki ilişki üzerinde durulmaktadır. İkinci olarak, yasa ile siyasi güç arasındaki ilişki ön plana çıkartılarak, yasanın devletin bir iradesi olduğuna yönelik bir tanımlama yapılmaktadır. Son olarak yasanın 'iyiler' arasında aranması gerektiği ifade edilerek, yasanın ahlak ile bağlantısına dikkat çekilmektedir. Bu tanımlamalar ise sırasıyla, kulağa oldukça tanıdık gelecek tarihçi-sosyolojik hukuk, hukuki pozitivizm ve doğal hukuk akımları ile önemli ölçüde uyum göstermektedir ${ }^{14}$. İşte Minos diyaloğu tüm bu akımların haberini binlerce yıl öncesinden vermektedir. Bu kapsamda, Minos'ta yer alan söz konusu perspektiflerin -zamanla kendi içlerinde geçirdikleri değişimler ya da dönemden döneme sahip oldukları ağırlıklardaki farklılıklar bir yana-geçici olmaktan çok uzak oldukları anlaşılmaktadır.

Minos diyaloğunun ortaya çıktığı, milattan önceki dönemden yirminci yüzyılın başlarına doğru yaklaşıldığında da literatürde bu üç ana ekolü kapsayacak şekilde ifadelere çokça rastlanmaktır: "Hukukçuları, hukukun doğasına ve hukuka hangi perspektiften yaklaşılması gerektiğine ilişkin görüşleri doğrultusunda üç ana gruba ayırmak mümkündür. Bu grupları analitik, tarihçi ve felsefi ekoller olarak adlandırabiliriz"15. Aynı yönde, "hukuka ilişkin teoriler; analitik, tarihçi ve etik boyut olmak üzere üç dala ayrılabilir" şeklindeki açıklamaların örneklerinin ${ }^{16}$ çoğaltılabilme imkânı bir yana dikkat edilmesi gereken nokta, yaklaşık yüz yıl öncesinde üç farklı perspektifin varlıklarını korumakta olduğu hususudur. Belirtmek gerekir ki buraya kadar ortaya koyulan tüm görüşler tutarlı hatta birbirleriyle örtüşen bir sarmal şeklinde

13 Harold Berman, The Nature and Functions of Law, Brooklyn, Foundation Press, 1958, s.20,21.

14 Brian Tamanaha, A Realistic Theory of Law, Cambridge, Cambridge University Press, 2017, s.39. (Bu eser, sonraki atıflarda Tamanaha, Realistic Theory şeklinde kısaltılacaktır).

15 Roscoe Pound, "The Scope and Purpose of Sociological Jurisprudence: I. Schools of Jurists and Methods of Jurisprudence," Harvard Law Review, C:24, S:8, 1911, s.591,592.

16 John Salmond, Jurisprudence, London, Sweet and Maxwell Press, 1924, s.4. 
ilerlemektedir. Diğer deyişle, Minos diyaloğuyla paralel olarak, yirminci yüzyılın başında da hukuka ilişkin teoriler; (zaman içerisinde farklı isimler alsalar da) hukuk ve ahlak hukuk ve devlet - hukuk ve toplumun tarihsel gelişimi arasındaki ilişkiyi ön planda tutmakta olan ekoller olarak üç kola ayrılmaktadır. Ancak bu bölümün başlığı hatırlandığında, cevaplanması gereken önemli soru varlığını korumaktadır: $O$ halde kayıp olan şey nedir?

Bu soruyu cevaplandırmak amacıyla yirmi birinci yüzyılda kaleme alınan eserlere göz atmak suretiyle günümüze yaklaşarak, bir asır öncesindeki hukuk teorisyenlerini şaşırtması muhtemel kimi açıklamalara yer verilmesi gerekmektedir. Bunlardan ilki, "son birkaç yüzyılda, birbirlerine rakip iki temel felsefe geleneği ortaya çıkmıştır. Bunlardan daha eski olan ve geçmişi Hristiyan bilimine dayanan gelenek, doğal hukuk olarak adlandırılmaktadır. Söz konusu doğal hukuk teorileri Jeremy Bentham ve John Austin gibi teorisyenler tarafından ortaya koyulan hukuki pozitivizm geleneği tarafından şiddetle sorgulanmaktadır" şeklinde karşımıza çıkmaktadır ${ }^{17}$. Literatürde bu yönde var olan örnekleri çoğaltmak mümkün olup ${ }^{18}$, sayıca oldukça fazla eserde doğal hukuk teorisi ve hukuki pozitivizm akımının standart şekilde yerlerini muhafaza ettikleri görülmektedir. Bu doğrultuda, hukuk kuramına yönelik kaleme alınan birçok eserde izlenen rota, ilk olarak doğal hukuk kuramı ve hukuki pozitivizm ile başlamakta, ardından gelen hukuki realizm akımını ise güncel okullar ya da diğer kuramsal yaklaşımlar başlıkları takip etmektedir ${ }^{19}$.

İşte tam da bu noktada 'kayıp olan şeyin' tespit edildiğinden bahsedilebilmekte; Minos'tan beri varlığını koruyan üç ana akımın, günümüze yaklaşıldıkça literatürdeki çoğu eserde ikiye düştüğü söylenebilmektedir. Ayrıca bu tespiti kuvvetlendirecek nitelikte ana ekollerin zaman içerisinde yaşadıkları değişim, bir hukuk tarihçisi tarafından kaleme alınan satırlarda şu şekilde kendini göstermektedir: "şayet tarihçi hukuk akımı ölü kabul ediliyorsa..." ${ }^{20}$. Çağdaşı sayılacak başka bir metinde ise "tarihçi hukuk akımının önemli ölçüde kaybolduğuna" ilişkin ifadelerin yer aldığı görülmektedir ${ }^{21}$. Görünüşe bakılırsa tarihçi hukuk akımının, tarih sahnesinden yok olduğu ileri sürülmektedir. Ancak burada 'hukuk teorilerinin kayıp kolu, tarihçi hukuk

17 Andrei Marmor, "The Nature of Law," Stanford Encyclopedia of Philosophy, https://plato.stanford.edu/entries/lawphil-nature/ (01.01.2021); Aynı yönde Solum, yazısında hukukun doğasına ilişkin sosyolojik yaklaşımların varlığına değinse de "hukuk nedir?" sorusunun birbiriyle yarışmakta olan iki adet cevabının olduğundan bahsetmektedir. Bu cevaplardan birinin doğal hukuk teorisi, diğerinin ise hukuki pozitivizm tarafından ortaya koyulduğunu ileri sürmektedir. Larry Solum, "Legal Theory Lexicon: The Nature of Law," Legal Theory Blog, https://lsolum.typepad.com/legaltheory/2020/06/legal-theory-lexicon-the-nature-of-

law.html(05.01.2021). Yine aynı şekilde Himma'nın 'Hukukun Doğası' başlıklı eseri, yalnızca doğal hukuk akımı ve hukuki pozitivizm arasında geçen tartışmaları kapsamaktadır. Kenneth E. Himma, The Nature of Law: Philosophical Issues in Conceptual Jurisprudence and Legal Theory, Brooklyn, Foundation Press, 2011. Bu örneklerin bir araya getirildiği eser için bknz. Brian Tamanaha, "The Third Pillar of Jurisprudence: Social Legal Theory," William and Mary Law Review, C:56, 2015, s.2236, dn.1,2. (Bu eser, sonraki atıflarda Tamanaha, Third Pillar şeklinde kısaltılacaktır).

18 Bu yönde literatürde yer alan eserlere ilişkin örnekler için bknz. Tamanaha, Third Pillar, s.2236, dn.5.

19 Tamanaha, Third Pillar, s.2236.

20 Harold Berman, "The Historical Foundation of Law," Emory Law Journal, C:54, 2005, 18. (Bu eser, sonraki atıflarda Berman, Historical Foundation şeklinde kısaltılacaktır).

21 Brian Bix, Jurisprudence: Theory and Context, Durham, Carolina Academic Press, 2012, s.276. 
akımıdır' şeklindeki bir yanlış anlaşılmanın önüne geçmek amacıyla tarihçi hukuk akımının, ilerideki başlıklar altında ele alınacak olan hukukun kayıp kolunun altında bulunan teorilerden yalnızca biri olduğunun altı çizilmeli; söz konusu kayıp hukuk teorisinin yeni etiketi için biraz daha beklenmesi gerekmektedir.

Şimdi ise hukuk teorilerinin kayıp koluna ait, hukuk ve toplum arasındaki ilişkiyi ön plana çıkartan teorilerin başında gelen tarihçi hukuk akımına ilişkin önceki paragraflarda ortaya koyulan savların hatalı olduğu iddiasıyla bu çalışmanın kahramanı olan Brian Tamanaha'nın adını anma vakti gelmektedir. Şöyle ki Tamanaha ilk olarak, (yukarıda iki sayfa boyunca yer verilen) tarihçi hukuk akımının ortadan kaybolduğuna ilişkin düşünceleri ${ }^{22}$-hukuk kavramının sorgulanmasına yol açan provokatif nitelikteki ${ }^{23}$ eserinde ${ }^{24}$ - ele alarak, bunların görünüşte doğru kabul edilebilse de özünde yanlış olduklarını ileri sürmektedir. Zira tarihçi hukuk etiketinin kullanılmasına ara verilse de bu ekol tarafından benimsenmiş temel iddialar, diğer deyişle hukuk teorilerinin üçüncü ayağını oluşturan savlar geçerliliğini korumaya ve yayılmaya devam etmektedir ${ }^{25}$.

Bu noktada Minos-Kayıp Hukuk Teorisi-Brian Tamanaha arasında bulunan, ilk etapta tespit edilmesi zor ilişkinin yavaş yavaş ortaya çıkmaya başladığını ifade ederek ve henüz bir tohum halindeki bu bağın ilerleyen başlıklar altında ağaca dönüşeceğini belirterek, konuya Tamanaha'nın tarihçi hukuk akımına ilişkin düşünceleri ve (bu düşünceleri ortaya koyarken yararlandığı eserler ile) devam edilmesi gerekmektedir.

Öncelikle, on dokuzuncu yüzyılın başlarında tarih sahnesinde yerini almaya başlayan ve bir süre sonra ortadan kaybolduğu iddia edilen tarihçi hukuk akımının hukuk, toplum ve ekonomik koşullar arasındaki ilişki üzerinde yükseldiğini söylemek mümkündür ${ }^{26}$. Daha kapsamlı bir tanımla, bu ekole bağı teorisyenler olması gereken hukuku ve olan hukukun kaynağını toplumun gelenek ve görenekleri ile ilişkilendirmekte, hukuk kurallarının ve adalet kavramının anlamının toplumun tarihsel değerlerinde ve kendi kültüründe bulunacağını iddia etmektedir ${ }^{27}$. Bununla beraber Minos'ta geçen, aynı toplulukların mütemadiyen aynı yasaları kullanmadıkları iddiasına da gönderme yaparak- tarihçi perspektifte sanılanın aksine değişimin oldukça önemli bir yer teşkil ettiğinin de altı çizilmelidir. Hukuk, toplumun bir ürünü olup, toplumdaki gelişmelerle bağlantılı olarak sürekli değişmekte ve gelişmektedir ${ }^{28}$.

\footnotetext{
22 Bknz. dn.17, 20 ve 21.

23 Bix, bu eseri "provokatif" olarak nitelendirmiştir. Brian Bix, "A New Historical Jurisprudence?" Washington University Law Review, C:95, 2018, s.1035. (Bu eser, sonraki atıflarda Bix, Historical Jurisprudence şeklinde kısaltılacaktır).

24 Tamanaha'nın bu eseri, 2019 yılında İsviçre'de düzenlenen IVR Dünya Kongresinde, 2016-2018 yılları arasında Hukuk Felsefesi alanında en iyi kitap ödülü ve 2018 yılında Prose ödülleri hukuk kategorisinde mansiyon ödülüne layık görülmüştür.

25 Tamanaha, Realistic Theory, s.12-14. Bu noktada Tamanaha'nın, 15. ve 16. dipnotlarda bulunan çalışmalara, görüşünü desteklemeleri amacıyla kendi eserinde yer verildiği belirtilmelidir. Tamanaha, Realistic Theory, s.12.

26 Peter Stein, "The Tasks of Historical Jurisprudence" The Legal Mind: Essays for Tony Honore, (ed.) Neil MacCormick ve Peter Birks, Oxford, Clarendon Press, 1986, s.293.

27 Berman, Historical Foundation, s.13.14.

28 Tamanaha, Realistic Theory, s.17,18.
} 
Son olarak belirtmek gerekir ki -genellikle ana akımlar arasında kendisine yer bulamadığından bahsedilen- tarihçi hukuk ekolü, bir yandan bilim-öncesi döneme ait olduğunu ortaya koyduğu doğal hukuk kuramına; diğer yandan dünya üzerinde geçmişte ve mevcut dönemde var olmuş/olan birbirinden farklı hukuk sistemlerinin çeşitliliği karşısında sınırlı bir akım olarak görünmesine neden olduğu hukuki pozitivizm akımına, güçlü bir rakip olma niteliğini taşımaktadır.

Yirminci yüzyılın başlarında kendisine gösterilen ilgiyi yitiren tarihçi hukuk akımının bu kaderi yaşamasının altında yatan nedenler ise ayrı bir tartışma konusu oluşturmaktadır. Öncelikli gerekçe olarak, bu ekole ait teorisyenler tarafından sistemli bir kuramın ortaya konulamadığı gösterilmektedir. Bununla beraber, dönemin köklü ve hızlı toplumsal değişimlere sahne olması; ekonomik ve çalışma hayatına, sosyal refaha ilişkin tartışılan düzenlemelerin ortaya çıkması, idari devletin gelişmesi gibi yaşanan olayların geçmişle bağı bulunan hukuk okuluna ilgiyi azalttığı ve geleneklere, değişen toplumun ihtiyaçları ile bağlantılı organik büyümeye ilişkin konuşmaların güncelliğini yitirdiği ileri sürülmektedir ${ }^{29}$.

Ancak tarihçi hukuk okulunun güncelliğini yitirmesinin arkasındaki nedenleri tartışmak ilgi çekici olsa da bu tartışmalar Tamanaha'ya göre, hukuk ve toplum arasında bulunan ilişki üzerine yoğunlaşan kuramların temel argümanlarının gelişerek devam ettiği noktasının gözden kaçırılmasına neden olmaktadır ${ }^{30}$. Nitekim hukuk literatürüne bakıldığında genellikle tarihçi okulun belirli bir dönemde öldüğünün ve yerini sosyolojik okulun aldığının ileri sürülmekte olduğu görülmektedir ${ }^{31}$. Bu düşünce Tamanaha'ya göre hatalı bir anlayıştan ibaret olup, tarihçi ve sosyolojik okul, daha kapsamlı bir hukuk geleneğinin (hukukun kayıp kolunun) farklı türlerini oluşturmaktadır. Diğer deyişle, tarihçi ve sosyolojik okulun paylaştıkları temel savlar ortak olup, buna karşın vurgu yaptıkları noktalar ve benimsedikleri yöntemler birbirlerinden farklılaşmaktadır. Bu doğrultuda tarihçi okulun süresinin dolarak, yerini sosyolojik okula bıraktığı iddiası doğru kabul edilemeyecektir ${ }^{32}$. Diğer yandan bu iki akımın bir bütünün yarısını oluşturdukları söylenemese de iki ekolün arasındaki bağın çok kuvvetli olduğunu da ifade etmek gerekmektedir. Nitekim sosyolojik okul, tarihçi okulun karakterini belirleyen iddiaları paylaşmakta ve bu nedenle tamamıyla ondan ayrı düşünülememektedir. Tamanaha'ya göre bu iki akımın arasındaki ilişkinin kökleri ise hukuku hem tarihin hem de toplumun mevcut koşullarının bir ürünü olarak değerlendiren ve izlediği yöntemde tarih ve sosyolojiyi birleştiren Montesquieu'ya kadar uzanmaktadır ${ }^{33}$.

Burada bir parantez açarak yukarıda belirtilen görüşler kapsamında Tamanaha'nın iç içe geçmiş üç itirazının üzerinde biraz daha durmak gerekmektedir. Böylece ilerleyen başlıklar altında, Tamanaha'nın hukuk teorilerinin üçüncü koluna ve

\footnotetext{
29 Tamanaha, Third Pillar, s.2250,2251.

30 Tamanaha, Realistic Theory, s.22.

31 Tamanaha'ya göre, bu iki akımın onlarca yıl önce dile getirdiği kimi fikirler günümüzde hatalı olarak hukuki realistlere atfedilmektedir. Bu konuya ilişkin olarak bknz. Tamanaha, Realistic Theory, s.26; Brian Tamanaha, “Understanding Legal Realism,” Texas Law Review, C:87, S.4, s.731 vd.

32 Tamanaha, Realistic Theory, s.23, dn.84.

33 Tamanaha, Realistic Theory, s.24.
} 
ortaya koyduğu hukuk kuramına yönelik yer verilen açıklamalar daha net bir şekilde anlaşılabilecektir. Buna göre, söz konusu itirazlardan ilk ikisi, tarihçi hukuk akımının 'ölü' ilan edilmesine ve yerini sosyolojik okula bıraktığı iddialarına; üçüncü ve daha kapsamlı itirazı ise literatürde hukuk teorilerinin doğal hukuk ve hukuki pozitivizm olarak iki temel kola ayrılmasına ilişkindir. Nitekim Tamanaha'ya göre, hukuk akımlarının eksik bırakılan, (altında tarihçi ve sosyolojik okulu da barındıran) üçüncü ve esaslı bir kolu daha bulunmaktadır. Bu gelenek hem doğal hukuk hem de hukuki pozitivizme güçlü bir rakip olarak birkaç yüzyıldır varlığını sürdürmekte ise de günümüzde (aşağıdaki başlıklar altında değinilecek) çeşitli nedenlerle fazla tanınmamaktadır ${ }^{34}$.

Bu kapsamda Tamanaha, hukuk teorilerinin üçüncü kolundan bahsederken, iddiasının hukuka ilişkin geliştirilen her teorinin bu üç yaklaşımdan birine sıkıştırılması zorunluluğunu taşımadığının ve mevcut hukuk teorilerini kategorize etmenin tek yolunun da bu olduğunu düşünmediğinin altını çizmektedir. Tamanaha'ya göre, iddiası bu denli kapsamlı olmayıp, çok daha sınırı bir nitelik taşımaktadır. Buna göre, hukuk teorilerine ilişkin dile getireceği uzun bir geçmişe sahip üçüncü akım, doğal hukuk teorisi ve hukuki pozitivizm karşısında tutarlı bir alternatif oluşturmakta; bunun kabul edilmesi ise hukuka ilişkin teorik tartışmalar açısından oldukça fayda sağlamaktadır ${ }^{35}$.

İşe bu noktada Tamanaha'nın yukarıda ele alınan itirazları ve tezini kuvvetlendirmek amacıyla gönderme yaptığı eserler hatırlandığında, hukuk teorilerinin üçüncü kolu olarak, -üzerinde fazlaca durduğu- tarihçi hukuk ekolünü ileri süreceğinin düşünülmesi mümkün olsa da bu konuda hızlı sonuca varmak hatalı -ya da daha doğru bir ifade ile eksik- bir yargıya ulaşılmasına neden olmaktadır. Peki, o halde nedir bu eksik, üçüncü kol?

\section{HUKUK TEORILERININ ÜÇÜNCÜ KOLU: TOPLUMSAL HUKUK TEORISI}

Bu teori adından da anlaşılacağı üzere hukukun doğasına toplumsal bir bakış açısı sunmaktadır. Ancak Tamanaha, hukuk teorilerinin üçüncü kolu olarak ortaya koyduğu toplumsal hukuk teorisine ilişkin ayrıntılı bilgi vermeden önce önemli bir konuya dikkat çekmektedir. Şöyle ki hukuka dair ileri sürülen bütün teorilerin merkezinde hukukun sosyal niteliği ile ilgili yaygın varsayımlar bulunmaktadır. Bu varsayımlar ise kendi başlarına birer hukuk teorisi olarak değerlendirilmemelidir. Nitekim hukuka ilişkin geliştirilen teoriler, hukukun ne olduğuna ve işlevine yönelik açıkça formüle edilmiş önermelerden oluşmaktadır. Bu kapsamda, mevcut hukuk akımlarına göz atıldığında hukuki pozitivizm, sonuç ya da içerik itibarıyla kötü olup olmamasına bakılmaksızın, resmi görevliler tarafından hukuk olarak uygulanan herhangi bir şeyin hukuk olduğuna ilişkin ortak kabulü (varsayımı); doğal hukuk teorisi, hukukun adil olduğu ya da olması gerektiği ve ahlakın bir anlamda nesnel olduğu yönündeki yaygın inancı (varsayımı) içermektedir. Toplumsal hukuk teorisi ise hukukun kimi amaçlar doğrultusunda araç olarak kullanılan ve toplumla bağlantılı olarak gelişen

\footnotetext{
34 Tamanaha, Third Pillar, s.2237.

35 Tamanaha, Third Pillar, s.2237,2238.
} 
ve değişen toplumsal bir kurum olduğu şeklindeki anlayış (varsayım) üzerinde yükselmektedir ${ }^{36}$.

Tamanaha'ya göre, herhangi bir kimsenin ya da herhangi bir hukukçunun aralarında bir çelişki ya da uyumsuzluk olmaksızın bu üç varsayımın hepsini aynı anda benimsemesi mümkün olmaktadır. Örneğin, bir kimsenin hukukun ahlaka aykırı kabul edildiğinde dahi hukuken geçerli olduğuna; bununla beraber hukukun adil olması gerektiğine ve kimi ahlaki değer ya da normların objektif olarak doğru olduğuna; aynı zamanda da hukukun kimi amaçlar doğrultusunda kullanılan toplumsal bir kurum olduğuna yönelik varsayımların hepsini sahiplenmesi olanaklı görülmektedir. Ancak bu varsayımlar ilişkilendirildikleri akımlardan farklı bir akım altında bulunan bir teorinin içerisinde yer aldığında ya da bir teorinin içerisinde birden fazla varsayım söz konusu olduğunda; bu teorisyenin hangi akım altında değerlendirileceğine ilişkin birtakım belirsizlikler ortaya çıkmaktadır. Bu durumun oluşmasının arkasında ise söz konusu varsayımlar ile hukuk teorileri arasındaki çizginin çizilmesinde, diğer deyişle bunlar arasındaki ayrımın belirtilmesindeki başarısızlık yatmaktadır. Nitekim tekrar belirtmek gerekir ki bir teorisyenin bu varsayımlara odaklanan teorilerden bağımsız şekilde bir ya da birden fazla varsayımdan hareketle kendi teorisini oluşturması mümkün olmaktadır ${ }^{37}$.

Tamanaha'nın eserinde her şeyden önce bu noktaya dikkat çekmesindeki gerekçe için ise çok fazla beklemek gerekmemektedir. Bu doğrultuda, hukuka dolaylı yoldan evrimsel, işlevselci ya da sosyolojik perspektiflerle yaklaşan her hukuk teorisyeninin, toplumsal hukuk teorisi çatısı altında kabul edilmesi zorunluluğu bulunmadığını ileri süren Tamanaha; amacının daha ziyade tarihçi ve sosyolojik hukuk ekolünün merkezinde yer alan, hukukun sosyal niteliğine ilişkin görüşlerin izlerini sürerek bu görüşlerin, onlar üzerine inşa edilen teorilerden bağımsız bir şekilde ne denli geniş bir alana yayıldığını göstermek olduğunu belirtmektedir. Zira mevcut duruma bakıldığında, hukukun çoğunlukla sosyolojik terimlerle incelendiğini, ancak bu teorilerin altında toplanacağı bir hukuk geleneğinin boşluğunun söz konusu olduğu görülmektedir. Çok genel bir ifadeyle, literatüre göz atıldığında hukuk ve ahlak arasındaki ilişkiyi ön plana çıkartan teorilerin doğal hukuk; hukuk ve devlet arasındaki ilişkiye odaklanan teorilerin hukuki pozitivizm şemsiyesi altında ele alınmakta olduğu görülmektedir. Ancak hukuk ve toplum arasında bulunan ilişki üzerine yoğunlaşmakta olan tarihçi hukuk, sosyolojik hukuk gibi teoriler kendilerine, alt dallarını oluşturacakları genel bir etiket bulamamaktadır.

Işste bu boşluğun doldurulması amacıyla toplumsal hukuk teorisi etiketini ileri süren Tamanaha, bu geleneğin hukuk teorilerinin önemli bir kolunu oluşturduğunu ve bu akımın altında bazı konularda aralarında fikir ayrılıkları bulunan teorilerin yer almasının mümkün olduğunun altını çizmektedir. Elbette bu ifade şaşkınlıkla karşılanmamaktadır. Nitekim Tamanaha'ya göre, gerek doğal hukuk akımı (örneğin, Finnis'in doğal hukuk anlayışı ile Fuller'ın prosedürel doğal hukuku) gerekse hukuki pozitivizm geleneğinin içerisinde (örneğin, Kelsenci ve Hartçı pozitivizm) radikal fikir

36 Tamanaha, Third Pillar, s.2262.
37 Tamanaha, Third Pillar, s.2263. 
ayrılıkları ve derin uçurumlar varlıklarını korumaktadır ${ }^{38}$. Bu nedenle toplumsal hukuk teorisini -aynı diğer iki gelenek gibi- bazı ortak noktalara sahip teorileri altında toplayan bir şemsiye olarak değerlendirmek gerekmekte ve bu şemsiye altında tek, baskın bir toplumsal hukuk teorisinden bahsetmek mümkün olmamaktadır. Peki bu gelenek altında değerlendirilebilmek için gereken hususlar, diğer deyişle bu akım altında bir araya gelen teorilerin sahip oldukları ortak noktalar nelerdir? Tamanaha'ya göre bunlar iki önermeye indirgenebilmektedir: Hukuk, (i) tabiatı gereği toplumsaldır ve (ii) en iyi şekilde ampirik (deneysel) çalışmalar aracılığıyla anlaşılabilmektedir ${ }^{39}$.

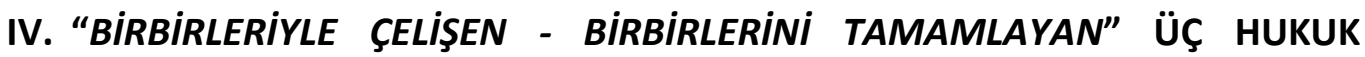 FELSEFESI AKIMI}

Hukuk teorilerinin eksik üçüncü kolunun kendisine bir isim bulmasıyla birlikte artık hukuk felsefesi akımlarını genel olarak doğal hukuk, hukuki pozitivizm ve toplumsal hukuk teorisi başlıkları altında incelemek mümkün hale gelmektedir. Bu kapsamda bir önceki başlığın son cümlesinden yola çıkarak, toplumsal hukuk teorisinin hukuka ampirik bir bakış açısıyla yaklaştığı; bununla beraber, geriye kalan iki farklı yaklaşımdan biri olan hukuki pozitivizmin hukuka kavramsal ve analitik açıdan, doğal hukuk teorisinin ise hukuka normatif açıdan yaklaştığını söylemek gerekmektedir. Farklı bir deyişle, hukuki pozitivizmde analitik felsefe, doğal hukuk teorisinde ahlak felsefesi, toplumsal hukuk teorisinde ise sosyal bilimler ön planda yer almaktadır. Burada "bilim" kavramını; tarih, ekonomi, sosyoloji, antropoloji, psikoloji, siyaset bilimi gibi ampirik çalışmalara dayalı tüm bilim dallarını kapsayacak şekilde geniş kullandığının altını çizmekte olan Tamanaha, ortaya koyduğu toplumsal hukuk teorisinin yokluğunda hukukun doğasına ilişkin teorik tartışmalarda önemli bir perspektifin eksik kaldı̆̆ına dikkat çekmektedir.

$\mathrm{Bu}$ doğrultuda (hukuki pozitivizmin bir ayağını oluşturan) analitik hukuk teorisinin ya da doğal hukuk akımının, hukukun sosyal bağlamını, tarihsel boyutunu göz ardı ettiklerinden dolayı bazı kör noktalara sahip olduklarını ileri sürmektedir. Örneğin, analitik hukuk teorisyenleri hukukun üstünlüğünün temel unsurları hakkında bilgi verebilmekte iken, bir toplumda bu kavramının nasıl geliştiğine ilişkin bir şey söyleyememektedir ${ }^{40}$. Isşte hukuk teorileri denildiğinde ön saflarda yer alan bu iki önemli hukuk geleneğinin, hukukun doğasına ilişkin tartışmalar açısından sahip oldukları kör noktaların ortadan kaldırılması amacıyla, kör nokta aynası olarak adlandırılabilecek toplumsal hukuk teorisi sahnede yerini almaktadır.

Buradan hareketle, aralarında çok eski tarihlerden bu yana husumet bulunan bahse konu üç farklı akımın birbirleriyle son derece ilişkili oldukları ve bunlardan herhangi birisinin göz ardı edilmesinin teorik tartışmalar açısından ciddi sorunlar yaratacağı; söz konusu üç yaklaşımın birbirlerinin sahip olduğu eksik yanları kapatmakta olduğu söylenebilmektedir. Kısacası, bir yandan birbirleriyle çelişen bu üç hukuk felsefesi akımı, diğer yandan farklı odak noktalarını ön plana çıkartarak

\footnotetext{
38 Tamanaha, Third Pillar, s.2264,2265.

39 Tamanaha, Third Pillar, s.2266.

40 Tamanaha, Third Pillar, s.2267-2269.
} 
birbirlerinin noksanlıklarını tamamlamakta ${ }^{41}$; bu nedenle birinin diğerini ortadan kaldırması mümkün olmamakta ve (güncel durumun aksine) üçü de eşit önem derecesine sahip bir şekilde hukukun doğasına ilişkin tartışmalarda saflarını korumaktadır. Bununla beraber Tamanaha'ya göre, şayet bir teorisyen hukuk kavramını derinden kavramak, tüm boyutlarıyla anlamak istiyorsa, aralarında anlaşmazlık bulunan bu üç perspektif hakkında da bilgi sahibi olmak zorundadır.

Burada bir parantez açarak, bir önceki paragrafta ve hatta bu bölümün başlığında (çalışmanın ilk sayfalarından bu yana kullanılmakta olan hukuk teorileri ya da hukuk akımları yerine) özellikle "hukuk felsefesi akımları" ifadesinin kullanımasının bir tesadüf olmadığını belirtmek gerekmektedir. Bunun nedenini; Tamanaha'nın bahse konu üç farklı yaklaşımı hukuk felsefesi akımları altında değerlendirmesinin karşısında, bu üç akımdan biri olan toplumsal hukuk teorisinin kimi nedenlerle hukuk felsefesi çatısı altında bulunamayacağı şeklinde yorumlanabilecek itirazlar oluşturmaktadır ${ }^{42}$. Bu itirazlara göre, yalnızca hukuki pozitivizm ve doğal hukuk teorileri hukuk felsefesi altında değerlendirilebilmektedir. Bu argümanları biraz daha detaylandırmak gerekirse, bir hukuk teorisinin tüm hukuk sistemleri açısından geçerli olması gerektiğinden, bunları karakterize eden unsurlar genel ve soyut nitelik taşımak zorundadır. Bu nedenle hukuk teorileri bünyesinde, kimi toplumların içerisinde bulundukları sosyal, ekonomik veya kültürel koşullar nedeniyle, hukukun salt bu toplumlarda sahip olduğu işlevler göz ardı edilmeli; diğer deyişle, belirli toplumların yerel koşullarından bağımsız şekilde, hukuk sistemlerinin evrensel olarak taşımaları gereken niteliklere odaklanılmalıdır.

$\mathrm{Bu}$ itirazlar ile hukuk felsefesi ve hukuk sosyolojisi arasındaki farklar ortaya koyulmaktadır. Buna göre hukuk sosyolojisi, belirli toplumlarda var olan/olmuş hukukun sahip olduğu biçim ve işleve yönelik ayrıntılı bilgi sağlamakta; hukuk felsefesi ise evrensel olarak tüm hukuk sistemlerinin taşıması gereken daha az sayıdaki özellik ile ilgilenmektedir ${ }^{43}$. Bu söylemler doğrultusunda, (sözde) evrensel olma niteliğinden uzak (!) ${ }^{44}$, toplum ve hukuk arasındaki ilişkiyi ön plana çıkartan ve ampirik çalışmalara dayalı toplumsal hukuk teorileri (hatalı olarak) hukuk felsefesi akımları altında kendilerine yer bulamamaktadır ${ }^{45}$.

Eserinde aynı duruşu sergileyen, hukuk felsefesi alanında günümüzde önde gelen bir diğer ismin ${ }^{46}$ sıra dışı ifadelerine göre ise, sosyal bilimler insan toplumunu incelediğinden dolayı hukukun genel anlamda ne olduğunu söyleyebilecek vasfa sahip

41 Tüm bu gerekçeler ışığında, Tamanaha hukuka ilişkin üç farklı perspektifi "Birbirleriyle Çelişen Birbirlerini Tamamlayan" şeklinde nitelendirmektedir. Tamanaha, Third Pillar, 2266.

42 Tamanaha bu noktada, birazdan görüleceği üzere Raz ve Shapiro'nun ileri sürdükleri itirazları hedef almaktadır.

43 Joseph Raz, The Authority of Law, Oxford, Oxford University Press, 2009, s.104,105.

44 Buraya bir ünlem koyulmasının nedeni ileride ayrıntılı olarak açıklanacaktır. Ancak kısaca bahsetmek gerekirse; kimi teorisyenlerin toplumsal hukuk teorilerini evrensel olma niteliğinden uzak olarak değerlendirmeleri karşısında Tamanaha, hukuka gerçekçi bir bakış açısı sunarak aslen doğal hukuk ve hukuki pozitivizm akımlarının yerel ve zamana bağlı oldukları şeklinde eleştiri getirmektedir.

45 Bu argümanlar karşısında Tamanaha 'sosyolojik hukuk' ve 'hukuk sosyolojisi' arasında ciddi farklar bulunduğunun altını çizerek, bu farkları ele aldığı güncel tarihli bir eser yayımlamıştır. Bknz. Brian Tamanaha, "Sociological Jurisprudence Past and Present", Law \& Social Inquiry, C:45, S:2, 2020, s.2230.

46 Scott J. Shapiro, Legality, Cambridge, Harvard University Press, 2011, s.406,407, dn.16. 
değildir. Insan-olmayan toplumların da bir hukuk sistemine sahip olabileceği gerçeği karşısında, sosyal bilimlerin ortaya koyduğu yargılar bir hukuk felsefecisi açısından önem taşımamaktadır. Farklı bir deyişle, temelinde sosyal bilimlerin bulunduğu hukuk teorileri yalnızca belirli insan topluluklarını ele aldığından, hukukun tüm olası örneklerini kapsayacak şekilde genel bir açıklama yapabilme açısından sınırlı bir niteliğe sahip olmaktadırlar. Buna göre, yalnızca hukuk felsefesi teorisyenleri -hem insan hem de uzaylı (!)- hukukuna ilişkin evrensel kuralları tanımlama yetisine sahiptir.

Elbette ampirik çalışmalara dayalı sosyal bilimlerin ön planda olduğu (toplumsal) hukuk teorilerinin hukuk felsefesiyle tamamıyla ilgisiz olduklarının ilan edilmesi Tamanaha'nın dikkatinden kaçmamaktadır. Bunun üzerine konuk olduğu bir yayında, "bir hukuk felsefecisi; hukuka ilişkin sosyolojik yaklaşımların insan toplumlarıyla sınırlı olduğundan hareketle genel hukuk bilimine yönelik çıkarımlar yapamayacağını, felsefi yaklaşımların ise diğer gezegenler için de (!) uygulanabilirliği olduğunu belirtmiştir" şeklinde bir açıklama yapmaktadır ${ }^{47}$.

Bu dışlayıcı duruşa karşı duran Tamanaha'ya göre, bazı güncel teorisyenlerin aynı çizgide ilerledikleri söylenebilse de daha eski tarihlerde hukuk teorisyenleri tarafından kaleme alınmış eserlerde çoğunlukla bu duruşun aksi savunulmakta ve söz konusu üç yaklaşım (isimleri zaman içerisinde farklılık gösterse de) hukuk felsefesi çatısı altında değerlendirilmektedir ${ }^{48}$. Tamanaha'ya göre bu dışlayış, hukuk teorilerinin oldukça soyut ve kısır bırakılması ile sonuçlanmaktadır. Zira toplumsal bir kurum (olan hukuk) hakkında çok az şey evrensel olarak doğru kabul edilebilmektedir. Bu kapsamda, hukuk teorilerini zamansız ve evrensel şekilde geçerli olarak sunmak amacıyla hukuku tarihten ve toplumdan soyutlayan teorisyenlerin hukuka ilişkin sosyolojik yaklaşımları dışlayıcı duruşları, her durumda hukukun toplumsal bir kurum olduğu gerçeği karşısında tökezlemeye mahkumdur ${ }^{49}$.

Bununla beraber, görevlerinin hukukun sahip olması gereken zorunlu ve temel niteliklerini belirlemek olduğunu iddia eden teorisyenlerin çoğu ortaya koydukları bu niteliklerin kaynağını açıklamamakta ve bu konuyu belirsiz bir şekilde ortada bırakmaktadır ${ }^{50}$. Ancak Tamanaha'ya göre tüm bu tartışmalar, toplumsal hukuk teorisinin -hukuk felsefesi akımlarına dahil olduğu kabul edilsin ya da edilmesinhukuka ilişkin önemli ve diğerleriyle eşit ağırlığa sahip bir yaklaşım olduğu gerçeğini değiştirmemektedir.

Bu noktada konunun akışına kısa bir ara vererek, Minos diyaloğu ile başlayan ve Tamanaha'nın zaman içerisinde hukuk teorilerinin ortadan kaybolan kolunu tespit

47 Brian Tamanaha, A Realistic Theory of Law, This Is Not A Pipe Podcast: 28.02.2019, https://www.tinapp.org/episodes/realistictheoryoflaw, dk.5:00-5:15 (19.12.2020) (Bu yayın, sonraki atıflarda Tamanaha, Podcast şeklinde kısaltılacaktır)

$48 \mathrm{Bu}$ konuda Tamanaha ilk olarak, Salmond ve Oakeshott'un eserlerini örnek göstermektedir. Tamanaha, Third Pillar, 2272. Bu eserler için bknz. Salmond, s.3,4; Michael Oakeshott, The Concept of a Philosophical Jurisprudence: Essays and Reviews 1926-1951, (ed.) Luke O'Sullivan, Imprint Academic, 2007, s.142-183.

49 Tamanaha, Third Pillar, s.2273-2275.

50 Tamanaha, Realistic Theory, s.65. 
ederek, farklı bir etiket ile onu ait olduğu yere koyma çabasına kadar uzanan yolun üzerinden kısaca geçilmesi hedeflenmektedir. Bu bağlantıların tekrar edilmesinin ilerleyen başlık altında yer alan, Tamanaha'nın toplumsal hukuk geleneğinin şemsiyesi altında konumlandırdığı, hukuka gerçekçi bir bakış açısını sunan teorisine geçişi kolaylaştıracağı düşünülmektedir.

Bu bağlamda Tamanaha öncelikle (i) binlerce yıl öncesine ait Minos diyaloğunda yer alan, hukuka ilişkin üç farklı perspektifi ortaya koymaktadır; ardından (ii) günümüze kadar gelindiğinde bu üç önemli gelenekten birinin literatürde dışlanmakta olduğunu ve çoğu eserde artık kendisine yer bulamadığını tespit etmektedir; (iii) bu yanlış tutumun hukuka yönelik teorik tartışmalar açısından ciddi eksikliklere neden olduğundan hareketle, hukuk ve toplum arasındaki ilişkilere odaklanan tüm teorileri bünyesinde barındırmak üzere, hukuk teorilerinin ihmal edilen, ancak diğerleriyle eşit öneme sahip olduğunu iddia ettiği üçüncü kolunu toplumsal hukuk teorisi etiketi altında ileri sürmektedir.

Bu etiketin, diğer deyişle odağında hukukun tabiatı gereği toplumsal olduğunu ve en iyi şekilde ampirik çalışmalar aracılığıyla anlaşılabileceğine ilişkin önermelerin bulunduğu bu akıma bir isim vermenin önemli olduğunun altını çizen Tamanaha, bunun nedenini; kabul görmüş bir isme sahip olmaksızın bir geleneğin pratikte var olmasının imkânsız olduğu şeklinde açıklamaktadır. Toplumsal hukuk teorisi etiketi, bir zamanlar göz önünde olan, ancak günümüzde sürgüne gönderilen kapsamlı bir teorik perspektife kimlik kazandırmaktadır. Bu kimlik ise hukuka alternatif bakış açıları sunan hukuki pozitivizm, doğal hukuk ve toplumsal hukuk teorisinin aralarında bulunan farklılıkları keskinleştirmeye ve zaman içerisinde felsefi kaygılardan giderek daha fazla etkilenen hukuk biliminin -gereken önemin verilmediği bazı perspektifleri de tartışmaların içerisine çekmek suretiyle- eksik noktalarının giderilmesine hizmet etmektedir ${ }^{51}$.

Böylece Minos-Kayıp Hukuk Teorisi-Brian Tamanaha üçgeninin tüm köşeleri tamamlandıktan sonra sıra nihayet dördüncü (iv) basamağa; bu üçgeni kareye döndürme zamanına gelmektedir. Bu basamakta, artık uygun koşulların oluştuğundan hareketle Tamanaha'nın toplumsal hukuk akımının altında konumlandırdığı "gerçekçi hukuk teorisi" adıyla savunucusu olduğu hukuk anlayışına yer verilmesi planlanmaktadır.

$\mathrm{Bu}$ kapsamda bir sonraki başlığa geçmeden önce belirtmek gerekir ki Tamanaha, yukarıda değinilen ${ }^{52}$; hukuka ilişkin sosyolojik yaklaşımların insan toplumlarıyla sınırlı olduklarından hareketle genel hukuk bilimine yönelik çıkarımlar yapamayacakları eleştirileri karşısında -aynı silahları kullanmak suretiyle- hukuki pozitivizm ve doğal hukuk akımlarının sahip oldukları sınırları ve aslen bu teorilerin zaman ve mekânla bağlantılı oldukları gerçeğini ortaya koyarak kendi teorisini inşa etmeye başlamaktadır.

\footnotetext{
51 Tamanaha, Third Pillar, s.2277.

52 Bknz. s.14.
} 


\section{GERÇEKÇi HUKUK TEORISI}

Bu başlık altında ilk olarak geriye dönerek, Tamanaha'nın hukuk teorilerinin üçüncü temel koluna ilişkin yapmış olduğu açıklamalarda "toplumsal hukuk akımının içerisinde kimi konularda aralarında fikir ayrılıkları bulunan farklı teorilerin yer alması mümkündür" ifadesini hatırlamak gerekmektedir. Böylelikle ilk etapta, savunucusu olduğu hukuk teorisinin konumlandırılacağı hukuk geleneğini canlandıran Tamanaha için, bu geleneğin altında yer alan teorilerden bir tanesinin de kendisinin ortaya koyduğu gerçekçi hukuk teorisi olduğunu söyleme vakti gelmektedir. Okuyucu açısından ise buraya kadar gelinen noktada Tamanaha'nın hukuk akımlarının üçüncü kolunu diriltmeye ve onu isimlendirmeye ilişkin çabasının nedeni net bir şekilde anlaşılmaktadır. Nitekim Tamanaha'nın öncelikle hukuk teorisinin, altında yer aldığı geleneği canlandırma gayreti -hiçbir teorisyenin ortaya koyacağı kuramın, literatürden neredeyse dışlanmış olan bir akım içerisinde yer almasını istemeyeceğinden hareketleakla uygun gelmektedir.

İkinci olarak, Tamanaha'nın "hukuka ilişkin geliştirilen teoriler, hukukun ne olduğuna ve işlevlerine yönelik açıkça formüle edilmiş önermelerden oluşmaktadır" ifadesi hatırlandığında ise akla gelen diğer husus, Tamanaha'nın ortaya koyduğu teori kapsamında, binlerce yıldır yanıtlanması ızdırap haline gelen "hukuk nedir?" sorusuna vermiş olduğu cevaba yöneliktir. Ancak bu cevaba ilişkin merakın sonraki başlıklara kadar devam etmesi gerekmekte; bu cevaptan önce konuya, Tamanaha'nın hukuk anlayışına yönelik bir ipucu niteliğinde (i) hukukun doğasına yönelik yapmış olduğu kısa bir açıklama ve ardından (ii) günümüze kadar gelen bazı hukuk tanımlamalarının neden başarısız olduklarına ilişkin tespitleri ile devam edilmesi planlanmaktadır.

(i) Hukukun bir doğası var mıdır? Bu sorunun cevaplanması için öncelikle gerçekçi hukuk teorisinin, Tamanaha'nın "sınırlı, soyut, tarihi dışlayan ve toplumdan kopuk" olarak nitelendirdiği doğal hukuk ve (hukuki pozitivizmin bir ayağını oluşturan) analitik hukuk teorisinin aksine; ampirik çalışmalara dayalı, sosyal, kültürel, ekonomik, siyasi, ekolojik ve teknolojik faktörlerle bağlantılı olarak gelişen holistik (bütüncül) bir hukuk vizyonu sunduğunu söylemek mümkündür ${ }^{53}$. Daha kapsamlı bir ifade ile Tamanaha'ya göre, toplumlar tarih boyunca örf adet hukuku, doğal hukuk, dini hukuk, devlet hukuku, uluslararası hukuk gibi farklı birçok hukuk türünü kolektif şekilde tanımakta ve bu hukuk türleri toplumlarda sosyal, kültürel, ekonomik, siyasi, ekolojik ve teknolojik faktörlerle bağlantılı olarak zaman içerisinde değişmekte ve gelişmektedir.

"Hukukun bir doğası var mıdır?" sorusunun ardından Tamanaha'nın teorisine ilişkin yapılan bu genel açıklamanın ilk etapta soru ile ilgisiz olduğu düşünülebilse de aslında bu genel bilgi, Tamanaha'nın hukukun doğasına ilişkin görüşlerini de içerisinde barındırmaktadır. Şöyle ki diğer akımların ortaya koydukları farklı açıklamalar karşısında Tamanaha'ya göre, toplumun birer ürünü olan farklı hukuk türleri, zaman içerisinde

53 Cambridge'in Tamanaha'nın kitabına ilişkin yayımlamış olduğu açıklamadan bir bölüm. Tamanaha, Realistic Theory, s.i 
toplumda yaşanan gelişmelere paralel şekilde sürekli değişim göstermekte ve evrimini devam ettirmektedir. İşte hukukun doğası bundan ibarettir ${ }^{54}$ !

(ii) Bugüne kadar ileri sürülen çoğu hukuk tanımının başarısız olmasının nedenleri nelerdir? Bu sorunun cevabını -bir önceki paragraftaki gibi- birkaç cümle ile açıklamak mümkün olmamakta ve bu nedenle Tamanaha'nın "hukuk nedir?" sorusuna vereceği yanıtla iç içe geçmiş bu tespitlerinin tam olarak anlaşılabilmesi için daha uzunca bir yol kat edilmesi gerekmektedir.

Bu kapsamda öncelikle gerçekçi hukuk teorisinin genel anlamda hukuka ampirik bir bakış açısı sunarak; sosyolojik, tarihsel ve antropolojik açıdan hukukun ne olduğunu ve işlevini ortaya koymaya çalıştığının altını çizmek gerekmektedir. Bu yönüyle de günümüzde karşımıza iki ana akım olarak çıkan; (i) ahlakın objektif ilkeleri ve bu ilkelerin pozitif hukuk ile ilişkisine odaklanan, sınırlı bir çerçeveye sahip doğal hukukla ve (ii) tüm hukuk sistemlerinin sahip olması gereken kriterlere ilişkin sorularla ilgilenen son derece soyut nitelikteki analitik hukuk teorisiyle tezatlıklar içermekte olduğu tahmin edilebilir bir hale gelmektedir. Tamanaha'ya göre, bu iki yaklaşımın hukuku, toplumdan ve tarihten soyutlamak suretiyle incelemeleri, hukuka ilişkin ileri sürmüş oldukları tanımlamalar açısından ciddi eksikliklerle sonuçlanmaktadır. Nitekim hukuk ve toplum arasında neden-sonuç bağlamında çift yönlü bir ilişki var olmaktadır. Diğer deyişle, hukukun iki yönü bulunmakta; hukuk bir yandan toplum içerisinde sosyal ilişkileri düzenlemeye hizmet etmekte iken diğer yandan toplumda var olan sosyal, ekonomik, siyasi hiyerarşilerden etkilenmektedir.

Hukuk ve toplum arasında bulunan bu sıkı ilişkiden hareketle; farklı zamanlarda ve farklı toplumlarda, değişik biçim ve işlevlerle karşımıza çıkan hukuk kavramının, bünyesinde çok fazla sayıda toplumsal, tarihsel kavram barındırması ve bir dizi yasanın dahi birden fazla işlevinin bulunması nedeniyle hukuka yönelik tek bir tanım yapmak mümkün olmamaktadır. Bu açıdan, genellikle çeşitli biçim ve işleve dayalı kombinasyonlardan oluşan hukuk tanımları, kaçınılmaz olarak ya çok geniş kapsamlı olmakta ya da hukuku tanımlamak açısından yetersiz kalmaktadır ${ }^{55}$.

Bu doğrultuda hukuk kavramına yönelik -Minos'tan beri- varlığını sürdüren üç kategoriden ilki, hukuku toplumsal yaşamı düzenleyen temel kurallar olarak görürken; ikincisi, kuralları açıklayan ve uygulayan kurumsallaşmış bir sistem olarak değerlendirmekte; üçüncüsü ise hak ve adaleti hukukun ayrılmaz bir parçası olarak kabul etmektedir. Bu kategoriler içerisinden -ikinci kategori ile uyumlu olacak şekildehukuku, devlet hukuku penceresinden tanımlamak günümüzde birçok teorisyen için cazip gelmektedir, zira devlet hukukunun yakın tarih ve günümüzde baskın bir hukuk türü olarak karşımıza çıktığı görülmektedir. Ancak diğer yandan devlet hukuku şeklinde addedilmek açısından gerekli niteliklerden yoksun olmalarına rağmen, dayattıkları kurallar ve hizmet ettikleri amaçlar göz önünde tutulduğunda, örf adet hukuku, uluslararası hukuk gibi hukuk türlerinin de hukuk kavramının içerisine dahil edilmesi kulağa mantıklı gelmektedir. Nitekim bu hukuk türleri de (aynı devlet hukuku gibi) tarihte ve günümüzde birçok toplumda çok sayıda insan tarafından hukuk olarak

\footnotetext{
54 Tamanaha, Realistic Theory, s.1,80.

55 Tamanaha, Realistic Theory, s.38; Tamanaha, Podcast, dk.11:04-11:30.
} 
dikkate alınmaktadır. Bununla beraber, bazı teorisyenlerin adaletin hukukun doğasında var olduğu ve hukukun adalete hizmet ettiği konusunda ısrar etmeleri de akla yatkın görünmektedir, çünkü hukuk bir taraftan da hak, meşruiyet gibi kavramları içerisinde barındırmaktadır. Bu kategorilere dayanılarak ileri sürülen hukuk tanımlanmalarına ilişkin farklılıkların devam etmesinin, diğer deyişle bir fikir birliğine varılamamasının nedeni ise; bu tanımlamaların biçimsel ve işlevsel analizler üzerine inşa edilmiş olmaları ve bu durumun da ne akıl ne de ampirik kanıtlarla çözülmesinin mümkün olmasıdır ${ }^{56}$.

Bu kapsamda Tamanaha'ya göre biçimsel ve işlevsel tanımların tümü "hukuk nedir?" sorusu karşısında başarısız bir görünüm sergilemektedir. Çünkü bu bağlamda hukuka ilişkin ortaya koyulan tanımlamaların hepsi hukuku içermekte, ancak hiçbiri 'yalnızca' hukuku içermemekte ve hiçbiri hukukun ne olduğuna ya da işlevlerine ilişkin tüketici bir tanım verememektedir. Illk durumda bu tanımlar salt hukuka özgü olmamakta ve içerisine hukuktan farklı kurumlar da dahil edilebilmekte; ikinci durumda ise hukukun tüm boyutlarıyla tanımlanması açısından yetersiz kalınmaktadır. Zira toplumsal hayat içerisinde farklı kurumların da hukuka atfedilen işlevleri üstlenmekte oldukları, diğer yandan özellikle modern hukuk sistemleri düşünüldüğünde tanımlarda belirtilen işlevlerden daha fazlasını kapsamakta oldukları görülmektedir. Bununla beraber, söz konusu tanımlara ilişkin en önemli sorun ise belirtilen biçim veya işlevden yoksun olan; ancak kolektif olarak tanınan örneğin, örf adet hukuku, dini hukuk, uluslararası hukuk gibi hukukun diğer tezahürlerini dışlamaları ve neredeyse tamamen devlet hukukuna odaklanmalarıdır!

Kolektif tanıma, kurumların varoluşları için vazgeçilmez bir koşul olup; devlet hukuku dışında hem tarihte hem de günümüzde kolektif olarak tanınan farklı hukuk türleri varlıklarını korumaktadır. Bu kapsamda, yokluğu durumunda sürekli bir hukuk sisteminden bahsetmenin mümkün olamayacağı kolektif tanımanın üç önemli unsuru bulunduğunu belirten Tamanaha, bu unsurları açıklamak için örnek olarak mülkiyet ve evlilik kurumlarını ele almaktadır. ilk olarak toplumdaki insanlar, mülkiyet ve evlilik kurumunu kolektif şekilde tanımakta; ikinci olarak toplumdaki insanlar, hukuk sistemini ve resmi görevlilerinin buna dayalı sahip oldukları yetkilerini tanımakta ve son olarak resmi görevliler hukuki süreç ve işlemleri kolektif şekilde tanımaktadır. İşte hukuk teorilerinin ileri sürdükleri hukuk kavramı, bu üç kriterin kusursuz biçimde birbirleriyle uyum içerisinde oldukları (örneğin, toplumdaki insanların mülkiyet ve evlilik olarak tanıdıklarının, resmi görevlilerin tanımladıklarıyla aynı olduğu varsayımı doğrultusunda) ideal bir hukuk imajı üzerine kurulmaktadır.

$\mathrm{Bu}$ üç kriterin birbirleriyle uyumlu oldukları varsayımı ile bağlantılı olarak, Tamanaha'nın 'ayna tezi' olarak adlandırdığı teze göre, devlet hukuku toplumun bir yansıması (aynası) olarak görülmektedir. Farklı bir deyişle, hukuk kuralları toplumun geleneklerinden ve ahlakından doğarak toplumsal düzeni sağlamaya hizmet etmektedir. Tamanaha ise bu teze şiddetle karşı çıkmakta; dünyanın farklı yerlerinde yürürlükteki devlet hukukuyla toplumlar arasında derin uçurumlar bulunduğunu ve bu durumun hukuk teorileri tarafından ortaya koyulan hukuk kavramları açısından göz ardı

56 Tamanaha, Realistic Theory, s.42,43. 
edilmekte olduğunu ileri sürmektedir ${ }^{57}$. İşte ayna tezini çürütmek suretiyle, yerine yeni bir hukuk anlayışı ortaya koymaya çalışan Tamanaha'nın bu konuya ilişkin itirazını bir cümle ile özetlemek mümkün olmaktadır: Genel hukuk teorileri tarafından ortaya koyulan hukuk kavramı, gerçekten genel midir ${ }^{58}$ ?

Tamanaha'ya göre, atıf yapmakta olduğu farklı çalışmalar göstermektedir ki örneğin, birçok Afrika ülkesi ${ }^{59}$ ve özellikle savaşların yıprattığı ülkelerde ${ }^{60}$ insanların önemli bir yüzdesi uyuşmazlıklarını devlet hukuku yerine kolektif olarak tanıdıkları yerel kurallar aracılığıyla çözüme kavuşturmakta ve birbirileriyle uyumsuz hukuk rejimleri toplumlarda yüzyılı aşkın süredir varlıklarını korumaktadır. Bu konudaki örnekleri çoğaltmak mümkün olmakla birlikte, altı çizilmesi gereken nokta; Tamanaha'nın karşısına aldığı hukuk akımları bünyesinde yer alan hukuk tanımlamalarında söz konusu hukuki çoğulluk gerçeğinin göz önünde bulundurulmadığına ilişkin olarak karşımıza çıkmaktadır ${ }^{61}$.

Bununla beraber -Minos diyaloğundaki öğrencinin de belirttiği üzere- farklı toplulukların farklı yasalara sahip olduklarını ve aynı toplulukların mütemadiyen aynı yasaları kullanmadıklarını görmek zor değildir. Günümüzde genel olarak kabul gören biçimsel ve işlevsel hukuk tanımları; aynı ülke içerisinde varlığını sürdüren ve geçmişte varlığını sürdürmüş farklı hukuk türlerini göz ardı etmelerinin yanında, farklı ülkelerin sahip oldukları farklı hukuk sistemleri de göz önünde bulundurulduğunda geçersiz bir hale gelmektedir. Aksi halde bu tanımların geçersiz hale gelmeyeceği ileri sürüldüğünde, bu tanımlamalar içerisinde belirtilen niteliklerle donatılmış hukuk sistemlerine sahip olmayan (ve geçmişte sahip olmamış) toplumlar hukuksuz kalmakta; bu toplumların hukuka sahip oldukları söylenememekte ve ayrıca bu niteliklerden yoksun, ancak kolektif olarak tanınmakta olan hukuk biçimleri hukuk kategorisinin dışında yer almaktadır.

Farklı bir deyişle, Tamanaha'nın eleştirdiği biçimsel ve işlevsel hukuk tanımlamalarını ortaya koyan hukuk teorisyenleri, teorilerinin yara almaması için ileri sürdükleri niteliklere sahip olmayan geçmiş ya da mevcut hukuk sistemlerinin, hukuk olmadıklarını ya da eksik, kusurlu, istisnai hukuk sistemleri olduklarını ilan etmektedirler. İşte bu durum, başlangıçta hukuk teorilerini oluştururken, yalnızca mevcut zamanda ve belirli bir toplumda geçerli olan devlet hukuku kavramına odaklanmalarından kaynaklanmaktadır ${ }^{62}$. Bununla beraber mevcut dönemde farklı

57 Brian Tamanaha, A General Jurisprudence of Law and Society, New York, Oxford University Press, 2001. (Bu eser, sonraki atıflarda Tamanaha, General Jurisprudence şeklinde kısaltılacaktır).

58 Genel hukuk bilimi belirli bir sisteme (batılı sistemlere) özgü, bunlarla sınırlı olmamalıdır. Tamanaha, General Jurisprudence, s.233.

59 L. Chirayath, Caroline Sage ve Michael Woolcock, "Customary Law and Policy Reform: Engaging with the Plurality of Justice Systems," Washington, DC, World Bank, 2005.

60 Debbie Isser, Customary Justice and the Rule of Law in War-Torn Societies, Washington, DC, U.S. Institute for Peace Press, 2011.

61 Tamanaha, Realistic Theory, s.47-56,77.

62 Tamanaha, Realistic Theory, s.66-69,78,79; Brian Tamanaha, "An Analytical Map of Social Scientific Approaches to the Concept of Law," Legal Theory and the Social Sciences, C: II, (ed.) Maksymilian Del Mar, Michael Giudice, New York, Routledge, 2010, s.501. (Bu eser, sonraki atıflarda Tamanaha, Analytical Map şeklinde kısaltılacaktır). 
toplumlarda ve hatta bu toplumlar içerisinde yerlerini korumakta olan farklı hukuk sistemlerinin varlığı yanında, "yavaş ya da hızlı değişim kaçınılmazdır"33" ifadesinden hareketle değişmiş, değişmekte olan ve değişeceği muhtemel hukuk kavramının evrensel ve zamansız biçimde sahip olması gereken özellikleri içeren tanımların kapsayıcı ve kalıcı olması da son derece zor görünmekte ve bu iddialar ortaya absürt durumların çıkmasına neden olmaktadır ${ }^{64}$.

Sonuç olarak, hukuk kavramına ilişkin yaygın kabul görmekte olan tanımlamaların; yalnızca mevcut zamanda var olan belirli bir toplumun penceresinden ve -hatta aynı toplum içerisinde benzer niteliklere sahip olmayan fakat kolektif olarak tanınan birçok sayıda hukuk türü varlığını korumakta iken- hukukun tek bir türü olan devlet hukuku üzerinden yapılması, evrensel ve zamansız oldukları iddialarına ters düşmektedir. Bu nedenle, hukuk kavramına yönelik olarak doğal hukuk ve özellikle analitik hukuk teorisyenleri tarafından ileri sürülen bu sınırlı tanımlara ilişkin olarak, yalnızca (i) belirli bir dönemde (ii) belirli bir toplumda var olan (iii) belirli bir hukuk türünü kapsamakta oldukları ve diğer tüm hukuk sistemlerinin ortaya koyulan bu hukuk kavramı merceğinden incelendiğinin söylenmesi mümkün görünmektedir.

Zira Tamanaha'ya göre, birbirlerine rakip doğal hukuk ve hukuki pozitivizm akımları hukuka yönelik -ironik olarak- farklı şekillerde aynı evrensellik iddiasını taşımaktadır. Bu kapsamda çoğu doğal hukuk ve analitik hukuk teorisyeni ${ }^{65}$ herhangi bir kanıta gerek duyulmaksızın kendiliğinden apaçık gerçekler olduklarını ileri sürdükleri 'kendi kabullerini' tüm hukuk sistemleri açısından zorunlu, evrensel gerçekler haline dönüştürmektedir. Böylece hukukun taşıması gereken bu özelliklerin neden ve nasıl seçildiği ve alternatif hukuk kavramlarının kendi teorileri karşısında neden geçersiz oldukları soruları çoğunlukla yanıtsıı bırakılmaktadır ${ }^{66}$.

O halde, yukarıda ortaya koyulan gerekçeler doğrultusunda Tamanaha'nın, oldukça sınırlı, eksik, dar kapsamlı ve daha doğru bir ifade ile "hukuk nedir?" sorusunu cevaplamak açısından başarısız olduklarını ileri sürdüğü yaygın olarak kabul edilen biçimsel ve işlevsel hukuk tanımlarının karşısında, daha kapsamlı bir hukuk tanımı mümkün müdür?

\section{HUKUKU TANIMLAMANIN BIR YOLU}

Bu başlık altında Tamanaha'nın "hukuk nedir?" sorusu karşısında başarısız bir görünüm sergilediklerini ileri sürdüğü tanımlamalar bir yana, problemin öncelikle sorunun kendisinden kaynaklandığı ihtimalinin üzerinde durulması gerekmektedir. Şöyle ki "hukuk nedir?" sorusu yanıltıcı olabilmekte ve dünya üzerinde farklı niteliklere sahip hukuk türlerinin var olduğu gerçeğinin göz ardı edilmesine yol açmaktadır. Deyim

63 Londra tarih müzesinin duvarında yazılı bir ifade.

64 Bu konuya ilişkin olarak bknz. Brian Tamanaha, "What is 'General Jurisprudence'? A Critique of Universalistic Claims by Philosophical Concepts of Law," Washington University School of Law, Legal Studies Research Paper Series, No:12-03-02-2012, s.23,24.

65 Bu noktada Tamanaha örnek olarak Finnis ve Shapiro'yu göstermektedir. Bknz. Shapiro, s.13; Finnis, s.81-83.

66 Tamanaha, Realistic Theory, s.71-73. 
yerindeyse yükte hafif pahada ağır bu soru, içerisinde (tekil) hukuk kavramını barındırarak teorisyenleri, doğru, tek bir hukuk tanımı vermeye ve bunun sahip olduğu nitelikleri ortaya koymaya yönlendirmektedir. Ancak "...hiçbir teorisyen (hukuku kavramsallaştırma çabası nedeniyle) suçlu tutulamaz. Şayet bir teorisyen öncelikle hukuku tanımlamanın bir yoluna sahip değilse ne teorik ne de ampirik açıdan hukuk hakkında bir şey söyleyemez... ${ }^{67 ”}$

İşte bu ifadede yer alan hukukun tanımlanmasına ilişkin bir yol bulunması ihtiyacına cevap olarak Tamanaha, "hukuk, toplumdaki insanların sosyal pratikler aracılığıyla 'hukuk' olarak kabul ettikleri ve riayet ettikleri şeylerdir"68" şeklinde (antiözcü) bir formül ileri sürmektedir. Bu formül akıllara Minos diyaloğundaki öğrencinin yasayı tanımlarken "yasa, yasa olarak kabul edilen şeylerden başka ne olabilir?" ifadesini getirmekle beraber bir hukuk tanımı vermemekte, ancak hukukun tanımlanmasına yönelik bir dizi kriter içermektedir.

Bu doğrultuda söz konusu formülün dört aşamada uygulanması gerektiğini belirten Tamanaha, ilk olarak (i) bir teorisyenin, toplumdaki insanların hukuku nasıl tanımladıklarını; farklı bir ifade ile hukuk türlerinden hangisini/hangilerini hukuk olarak dikkate aldıklarını tespit etmesi gerektiğini belirtmektedir. Tamanaha, eleştirdiği hukuk teorisyenlerinin genellikle bu aşamaya ilişkin fikir birliği içerisinde olduklarını, çünkü bu aşamayı görmezden gelerek; hukuku yalnızca devlet hukuku çerçevesinde ele alarak doğrudan ikinci aşamaya geçtiklerini düşünmektedir. İkinci olarak (ii) teorisyenin, konvansiyonel olarak kabul gören hukuk türü/türleri hakkında toplumun ne düşündüğünü anlamaya çalışmak zorunda olduğunun altını çizmektedir. Bu aşamaya ilişkin olarak ise Tamanaha, hukuk teorisyenlerinin toplumun hukuk hakkında ne düşündüğünü ihmal ederek, yalnızca hukukçuların, eğitimli insanların vb. hukuku nasıl anladıkları üzerine kurulu varsayımlardan hareket ederek kestirme bir yol izledikleri eleştirisini getirmektedir. Üçüncü olarak (iii) hukuk teorisyeninin, toplumda var olan hukuk türünün/türlerinin nasıl yapılandığı, yerine getirdiği işlevler gibi konularda ampirik bilgi edinmesi gerekmektedir. Bu noktada Tamanaha çoğu hukuk teorisyeninin (bir önceki sayfada bulunan eleştirilerden de hatırlanacağı üzere) ampirik verilere dayanmak yerine, herhangi bir kanıta gerek duyulmaksızın kendiliğinden apaçık iddialar olarak kabul ettikleri kendi kabullerini kullanarak üçüncü aşamayı atlamakta olduklarını düşünmektedir. Dördüncü ve son aşamada ise (iv) teorisyenin artık kavramsallaştırma sürecine geçmesi mümkün olmaktadır. Belirtilen aşamalar sonucunda edindiği veriler ışığında teorisyen artık hukuk türlerinin karakteristik özelliklere sahip olup olmadığı, hukuk türleri arasında ortak özelliklerin ya da belirli niteliklerin bulunup bulunmadığı gibi bir dizi soruyu değerlendirebilmeye hazır hale gelmektedir ${ }^{69}$.

Ancak burada hemen bir parantez açarak, önemli ve haklı bir itiraza yer vermek gerekmektedir $^{70}$. Buna göre, hukukun tanımlanmasına ilişkin izlenen süreçte, henüz

67 Leslie Green'in “The Forces of Law: Duty, Coercion and Power," Ratio Juris, C:29, S:2, 2016 eserinden hareketle Tamanaha, Realistic Theory, s.73. Parantez içerisindeki kısım benim tarafımdan eklenmiştir.

68 Tamanaha, General Jurisprudence, s.166,194.

69 Tamanaha, Realistic Theory, s.71-76.

70 Burada Gardner'ın Tamanaha'ya ilişkin kaleme almış olduğu eleştirinin ve karşılığında Tamanaha'nın kendisine vermiş olduğu cevabın kapsamları değiştirilmiştir. John Gardner, Law as a Leap of Faith: 
neyin hukuk olduğunu bilmeden önce, bu aşamalarda yer alan direktifler nasıl yerine getirilecektir? Daha açık bir ifade ile henüz hukuk kavramı tanımlanmamış iken hukukun ne olduğunu sormak ya da hukuk kavramı bilinmezken hukuk türlerine ilişkin araştırma yapmak kendi içerisinde bir kısır döngü oluşmasına neden olmaktadır. Elbette bu eleştiri karşısında ortada bir gizem bulunmadığını; günümüzde hukukun ne anlama geldiğine dair genel bir fikrin, daha doğru bir ifade ile hukuk teriminin temsil ettiği düşünce kümelerinin dünya çapında yaygın bir şekilde var olduğunu söyleyebilmek mümkündür. Ancak bu yaklaşım, günümüze ya da yakın geçmişe dair makul kabul edilebilse de eski dönemlere gidildikçe birtakım engellerle karşılaşmaktadır.

Şöyle ki bu yaklaşım, 'bize ait' olan hukuk kavramı penceresinden erken dönem toplumlarını değerlendirmek açısından yetersiz kalmaktadır. İşte Tamanaha bu bağlamda inceleme yapılırken, hukuk ya da hukuk sistemi olarak algılanan şeylerin ilk habercilerinin (öncüllerinin) var olup olmadığını görmek için günümüzden başlayarak, insanlık tarihinde geriye doğru gitmek suretiyle iz sürmek, başka bir deyişle soykütüksel yaklaşımın ${ }^{71}$ benimsenmesi gerektiğini düşünmektedir. Buradan hareketle gerçekçi hukuk teorisinin; insanlık tarihi boyunca ortaya çıkmış farklı hukuk görünümlerinin toplumlarda nasıl yapılandırıldıklarına, nasıl işlediklerine, üstlendikleri işlevlere ve ortaya çıkardıkları sonuçlara odaklı kapsamlı bir teori olduğu düşünüldüğünde, soykütüksel perspektifin hukukun bu yönlerine ilişkin detaylı bilgi edinilmesine yardımcı olacağından hareketle Tamanaha tarafından benimsenmesi akla uygun gelmektedir ${ }^{72}$.

Bu kapsamda eserinin ${ }^{73}$ önemli bir bölümünü soykütüksel yaklaşıma ayırmakta olan Tamanaha'nın buraya kadar ele alınanlar ışığında en büyük eleştirisinin; yaygın hukuk tanımlarının, hukukun tek bir görünümü olan devlet hukukuna odaklandıkları ve teorisyenlerin kendi sezgilerinden hareketle kimi özellikler belirleyerek tüm yer ve zaman için bu standartları ölçü olarak kullandıkları noktalarında toplandığı görülmektedir. Nitekim bu yaklaşımlar ardında, neden (genellikle batılı) modern devlet hukukunun, hukuk kavramı açısından evrensel standart olarak kabul edildiği, hukukun

Essays on Law in General, Oxford, Oxford University Press, 2012, s.298; Tamanaha, Realistic Theory, s.75.

71 Tamanaha, hukukun geçmişteki yapısını, yerine getirdiği işlevleri ve farklı sosyal çevrelerde nasıl tezahür ettiğini gözlemlemek amacıyla, hukukun farklı görünümlerine, sürekliliğine, zaman içerisinde geçirdiği değişimlere ve gelişimlere odaklanarak tarihte geriye doğru iz sürdüğünü belirtmektedir. Bunu soykütüksel perspektif olarak adlandırmakta olan Tamanaha'ya göre bu yaklaşım; hukuku sosyal, politik, ekonomik, ekolojik, teknolojik ve kültürel koşullara bağlı olarak gelişmekte ve zaman içerisinde değişmekte olan çeşitli sosyal karmaşıklık düzeylerine yerleştirmektedir. Tamanaha, Realistic Theory, s.82; Ancak Tamanaha'nın, 'soykütüğu' teriminin önem arz eden tarihçesine atıf yapmakta eksik kaldığı yönünde eleştiriler bulunmaktadır. Buna göre 'soykütüğü' terimi felsefi anlamda ilk kez Friedrich Nietzsche tarafından kullanılmış ve sonrasında Michel Foucault tarafından geliştirilmiştir. Tamanaha'nın gerçekçi hukuk teorisi bağlamında benimsediği soykütüğü yönteminin ise bu isimlerle ilişkisi eserinde net olmaktan çok uzaktır. Kevin P. Lee, "Realism and Jurisprudence: A Contemporary Assessment," Golden Gate University Law Review, C:49, S:2, 2019, s.82,83.

72 Tamanaha, Realistic Theory, s.76,77,81.

73 Tamanaha, Realistic Theory, s.82-117. 
sabit özelliklere sahip tek bir biçiminin mi olduğu ya da hukuk kavramının zaman içerisinde değişmesi ihtimalinin bulunması gibi üzerinde düşünülmesi gereken önemli hususlar bırakmaktadır ${ }^{74}$.

Işte çözümlenmesi gereken tüm bu sorunlar karşısında hukuka ilişkin farklı bir yaklaşım olarak soykütüksel bakış açısını benimseyen Tamanaha öncelikle hukukun; tarih sayfalarında geriye (ve ardından o zamandan tekrar ileriye) giderek, farklı sosyal çevrelerde izlerini sürmekte ve bu yolculuğun sonunda ise hukukun zaman içerisinde sürekli olarak değişip gelişerek farklı biçim ve işlevlerle karşımıza çıkmakta olduğunu belirtmektedir. Buna göre, ilkel toplumlarda var olan 'hukuk,' karmaşık toplumlarda başka bir şeye dönüşmekte ve modern toplumlara gelindikçe bir kez daha şekil değiştirerek daha kompleks bir hal almaktadır.

Bir önceki cümlede -sürü, kabile, şeflik gibi- "ilkel toplumlarda var olan 'hukuk'..." şeklindeki ifadenin kullanımı ise tesadüf olmaktan çok uzak olup, Tamanaha'nın önemli ve bu noktada tahmin edilebilir bir itirazına dayanmaktadır. Bu konuya ilişkin olarak Tamanaha, kimi antropolojik çalışmalara gönderme yaparak ilkel toplumların hukuka sahip olmadıklarını ileri süren teorisyenler ${ }^{75}$ karşısında, öncelikle tarihte "hukuksuz bir toplumun bulunmadığı"76" ya da "ateşsiz, dilsiz, dinsiz ve hukuksuz bir topluluk var olmamıştır, ancak bizim sosyal, dini ve hukuki kavramlarımızın ilkel kavramlar ile örtüşmemesi nedeniyle yapılması gereken şey, ilkel toplumlarda modern kurumlarımızın eşdeğerlerinin bulunmasıdır ${ }^{77 "}$ gibi ifadelerle karşıt görüşte yer alan antropologların eserlerini ortaya koymaktadır. Bu doğrultuda, antropologların konuya ilişkin fikir ayrılıklarına sahip olduklarını belirten Tamanaha, bu durumun hukuka verilen farklı anlamlardan kaynaklandığını düşünmektedir ${ }^{78}$.

Bu kapsamda hukuka sınırlı bir biçimde salt modern devlet hukuku penceresinden bakarak, kurumsallaşmış bir sistem gerekliliği arayan bir teorisyen elbette ilkel toplumlarda hukukun var olmadığına kanaat getirecektir ${ }^{79}$. Nitekim soykütüksel yaklaşımına göre, konu ve işlev bakımından bize ait hukuk kavramına benzerlik gösteren ilkel kurallar, organize bir sistemin varlığı aranmaksızın hukuk kabul edilmektedir. Ancak burada bir parantez açarak belirtmek gerekir ki Tamanaha, ilkel toplumlarda hukukun var olduğunu ileri sürerken ne bunun nesnel, evrensel anlamda hukuk olduğunu ne de ilkel toplumların konvansiyonel olarak bunları 'hukuk' olarak etiketlediklerini iddia etmektedir. Hukukun 'onların' değil, 'bizim' kavramımız

74 Tamanaha, Realistic Theory, s.82.

75 Örneğin, Shapiro s.35.

76 Sally Falk Moore, Law as Process: An Anthropological Approach, London, Routledge and Kegan Paul Press, 1978, s.215.

77 Julius E. Lips, “Government," General Antropology, (ed.) Franz Boas, New York, D.C. Heath and Company Press, 1938, s.489.

78 Tamanaha, Realistic Theory, s.84,89.

79 Tamanaha bu noktada özellikle, ilkel toplumların ikincil kurallardan yoksun olduğundan hareketle hukuk öncesi sisteme sahip olduklarını ileri süren Hart'ı; organize bir sistemin hukukun doğası için gerekli olduğu ve bu nedenle bu forma sahip olmayan bir şeyin hukuk sayılamayacağında ısrar eden Raz ve Shapiro gibi isimleri hedef almaktadır. Shapiro, s.15; Joseph Raz, "Can There Be Theory of Law?" The Blackwell Guide to the Philosophy of Law and Legal Theory, (ed.) Martin P. Golding ve William A. Edmundson, Oxford, Blackwell, 2005, s.328; Tamanaha, Realistic Theory, s.91,92. 
olduğunun altını çizmekte olan Tamanaha'nın iddiası yalnızca, hukuk olarak düşündüğümüz şeyin ilkel toplumlarda -bizim koşullarımızdan farklı ya da bir sistemden yoksun olsalar dahi- mevcut olduğuna yöneliktir.

Bu tezini kuvvetlendirmek amacıyla, soykütüksel yaklaşım ile ilkel toplumlardan başlayarak modern döneme kadar uzanan süreç içerisinde hukukun geçirdiği evrimleri ortaya koyan Tamanaha'ya göre hukuk, insanlık tarihi boyunca farklı biçim ve işlevlerle karşımıza çıkan sosyal bir büyüme olarak nitelendirilebilir. Buna göre, avcı toplayıcı toplumlarda hukuk; mülkiyet, kişiler, aile ve dini konulara ilişkin en basit şekilde koruma veya kısıtlama içeren kurallardan oluşmaktadır. Ardından yerleşik hayata geçilmesi ve toplulukların nüfuslarının artmasıyla beraber hukuka ilişkin farklı yapılar ve örgütlü bir güç ihtiyacı doğmakta, nitekim böylelikle bir yönetime bağlı hukuk sistemleri ortaya çıkmaktadır. Geçirdiği bu değişimlerle beraber hukuk artık farklı biçimlerde görülmeye başlamakta, bunların en önemlileri ise zorlayıcı uygulamaların ortaya çıkması ve mahkemelerin kurulması şeklinde kendisini göstermektedir. Bu noktada hukuk sistemleri bir yandan toplumsal ilişkileri düzenlemeye yönelik temel işlevini yerine getirmeye devam etmekte diğer yandan sosyal, ekonomik, siyasi hiyerarşiyi yapılandırmaktadır. Bununla beraber hem kendi hem de yönetimin sahip olduğu gücü arttırmaya hizmet eden hukuk, modern döneme gelindiğinde ise yeniden önemli bir değişim geçirmekte ve çok işlevli bir araç haline dönüşmektedir.

Ancak belirtmek gerekir ki bu çalışmada amaç hukukun, kısa bir özeti sunulan evrimine ilişkin ayrıntılı bilgi vermek değil, Tamanaha'nın bu araştırma sonucunda dikkat çektiği asıl noktayı ortaya koymaktır. Buna göre, hukukun değişim ve gelişim evreleri, kronolojik bir sıra ile incelendiğinde, sonraki aşamaların bir öncekinin yerini aldığı tarihsel bir süreç olarak değerlendirilebilmektedir. Oysa Tamanaha'ya göre bu oldukça yanıltıcı bir düşünceden ibaret olup, daha önceki aşamalarda karşımıza çıkan hukuk türlerinin çeşitli varyasyonları bugün de dünyanın farklı bölgelerinde varlığını korumakta ve diğer hukuk türleriyle etkileşimini sürdürmektedir. Buradan hareketle, her toplumun aynı ve tek bir hukuk türüne sahip olduğu, hukukun geçirdiği evrime ilişkin her toplumun tek tip ve kaçınılmaz olarak aynı yörüngeyi izleyeceği ${ }^{80}$ ve ayrıca hukukun evrimini tamamlayarak günümüzde artık son aşamaya gelindiği gibi düşünceler, hatalı yargılara varılmasına neden olmaktadır. Aksine hukuk, tarihsel ve toplumsal etkilere tabi olup, son derece değişken bir yapıya sahiptir. Kısacası, hukuk sürekli olarak yapım aşamasındadır ${ }^{81}$.

Işste Tamanaha'nın eleştiri oklarına hedef olan hukuk teorileri sadece hukuki çoğulluk karşısında değil, ayrıca hukukun geçirdiği bu değişim ve gelişim süreçleri karşısında da hukukun işlevlerini tespit etme açısından başarısız bir sınav vermektedir.

80 Bu ifadelerden hareketle Bix, Tamanaha'nın geliştirdiği teoriye ilişkin "modern tarihçi hukuk" yorumu yapmaktadır. Nitekim Tamanaha'nın teorisinde; tarih (soykütüksel yaklaşım çerçevesinde) yalnızca hukukun yapısı ve işlevinin zaman içerisinde ne denli değiştiğine ilişkin veri sunmakta, onun dışında tarihin değerine yönelik bir vurgu yapılmamaktadır. Bu nedenle, Tamanaha'nın gerçekçi teorisi aslında tarihle değil, daha ziyade sosyolojik bakış açısıyla, toplumsal bağlam ve ampirik araştırmalarla daha fazla ilgili görünmektedir. Bu ise klasik tarihçi hukuk akımını tam olarak yansıtmasa da modern tarihçi hukuk olarak adlandırılabilecektir. Bix, Historical Jurisprudence, s.1046.

81 Tamanaha, Realistic Theory, s.117; Tamanaha, Brian, "Insights about the Nature of Law From History," Kobe Memorial Lecture, Archiv fur Rechts- und Sozialphilosophie, C:15, 2017, s.44,45. 
Bu kapsamda Tamanaha'nın, önceki sayfalarda ${ }^{82}$ açılanmaya başlanan; bugüne kadar ileri sürülen çoğu hukuk tanımının başarısız olmasına ilişkin nedenleri saymaya devam etmekte olduğu görülmektedir. Peki, bu başarısızlık ile kastedilen nedir?

\section{HUKUKUN iKi YüZÜ}

Tamanaha'ya göre, eleştirdiği hukuk teorilerinin eksik olduğu tek alan, hukuk kavramına salt devlet hukuku penceresinden yaklaşarak 'hukuk' etiketi taşıyan diğer hukuk türlerini (örneğin, örf-adet hukuku, uluslararası hukuk) ihmal etmeleri ile sınırlı olmayıp, bu teorilerin çoğu -bir önceki başlığın son paragrafında belirtildiği üzerehukukun geçirdiği evrimleri de göz ardı ederek, hukuk ve toplumda yaşanan esaslı değişiklikleri ve bunların günümüzde ortaya çıkardıkları sonuçları hesaba katmayarak, hukuku yalnızca toplum düzenini sağlamaya ilişkin kurallar sistemi olarak düşünmektedir. Ancak günümüzde gelişim ve değişimini sürdürmekte olan devlet hukuku bu işlevden çok daha fazlasını kapsamakta; söz konusu bu temel işlev hukukun yalnızca tek bir yüzünü oluşturmaktadır. Buradan hareketle konunun ayrıntılarına geçmeden önce Tamanaha'nın itirazını şu şekilde ifade etmek mümkün hale gelmektedir: Hukuk kavramına hatalı olarak yalnızca devlet hukuku çerçevesinden yaklaşmakta olan hukuk teorileri, bununla beraber odaklandıkları tek hukuk türü olan devlet hukukunu da sınırlı bir şekilde ele almaktadırlar.

$\mathrm{Bu}$ doğrultuda Tamanaha'ya göre teorisyenler, hukuku genellikle toplumsal düzeni sağlama amacına yönelik kurallar sistemi olarak tanımlamaktadır ${ }^{83}$. Bu tanım ise hukuk kurallarının çoğunluğu için geçerli olsa da yasama organı tarafından yürürlüğe koyulan her hukuk kuralı, toplumsal ilişkileri düzenlemeye yönelik bir içeriğe sahip olmamakta ve devlet hukuku, yasa koyucunun seçtiği herhangi bir amaç doğrultusunda farklı biçimlerde karşımıza çıkabilmektedir ${ }^{84}$. Bu kapsamda, hukukun yalnızca bir boyutuna odaklanan mevcut hukuk teorilerinin sahip olduğu bu eksikliği gidermek ve modern hukuk sistemine daha uygun ve kapsamlı bir hukuk teorisi ortaya koymak üzere Tamanaha ilk olarak, (i) toplumsal düzeni sağlama işlevine yönelik temel kuralları (ii) devletin farklı amaçları ile ilişkili olan hukuk kurallarından ayırmaktadır ${ }^{85}$. Ancak bunlar, birbirlerinden tamamıyla kopuk alanlar olmayıp, hukukun etkileşim içerisinde bulunan iki farklı yüzünü oluşturmaktadır.

Buna göre hukukun ilk yüzünü (i) toplumsal düzeni sağlamaya yönelik temel kurallar oluşturmaktadır. Elbette hukuk, toplum içerisinde davranışları koordine etmeye ve taraflar arasında ortaya çıkan uyuşmazlıklara çözüm bulmaya ilişkin temel bir role sahiptir. Bu rol uyarınca tüm toplulukların, -sahip oldukları kültürel ve dini değerlere, ekonomik ve siyasi sistemlere ve karmaşıklık düzeylerine göre değişiklik gösterse de- bu konuları kapsayan kurallara sahip oldukları görülmektedir. Ancak bu noktada hatırlatmak gerekir ki Tamanaha'ya göre, devletin bu konuları düzenleyen

\footnotetext{
82 Bknz. s.18

83 Tamanaha burada Fuller ve Hart'ın hukuk tanımlamalarını örnek olarak göstermektedir. Bknz. H. L. A. Hart, The Concept of Law, Oxford: Clarendon Press, 1961, s.39; Lon Fuller, The Morality of Law, New Haven, Yale University Press, 1964, s.96,122.

84 Tamanaha, Realistic Theory, s.118-126.

85 Tamanaha bu ayrıma ilişkin Hayek'in eserini örnek almaktadır. Bknz. Friedrich Hayek, Law, Legislation and Liberty: Rules and Order, Chicago, University of Chicago Press, 1973.
} 
kuralları ile insanların fiilen uydukları kuralların her zaman birbirleriyle örtüştüğü varsayımı doğru olmayıp, aradaki bu uyumun gerçekleşmediği durumlarda devlet hukuku farklı kurallar dizisi içermekte iken, kimi topluluklar örf adet ya da dini hukuk kurallarına riayet etmekte ve bunların gerektirdiği şekilde hareket etmektedir.

Bununla beraber, doğrudan toplumsal düzeni sağlamaya ilişkin söz konusu kurallar oldukça istikrarlı bir niteliğe sahip olup, yavaş bir şekilde değişim göstermektedir. Bu değişimi gerçekleştirmek amacıyla toplumlarda bireylerin, kuruluşların ve sosyal grupların farklı alanlarda ileri sürdükleri itirazlara rastlamak mümkündür. Bu itirazlar, örneğin eşcinsel evliliğe izin verilip verilmeyeceği, boşanma sonrası çocuğun velayetinin nasıl belirlenmesi gerektiği veya sözleşmelerdeki haksız şartların bağlayıcı olup olmadığı gibi dini, kültürel, ahlaki ve ekonomik hususlara ilişkin olabilmektedir. Toplumda sürekli olarak varlığını koruyan bu tartışmalar sonucunda ise söz konusu toplumsal düzeni sağlamaya yönelik kurallar zaman içerisinde, ekonomik, siyasi, kültürel ve teknolojik faktörlere de bağlı olarak, yasama ve yürütmenin işlemleri ya da yargı kararları doğrultusunda kademeli olarak değişikliğe uğramaktadır.

Tamanaha, toplum düzenini sağlamaya yönelik bu kurallardan sonra, -hukukun ikinci yüzünü oluşturduğunu ve hukuka ilişkin tanımlamalarda göz ardı edildiğini düşündüğü- (ii) devletin diğer amaçları ile ilişkili olan hukuk kurallarını ele almaktadır. $\mathrm{Bu}$ kapsamda devletin çeşitli kurumları tarafından kullanılmakta olan hukuki düzenlemeleri, kullanım amaçlarına göre üç başlık altında incelemek mümkün görünmektedir. Bu başlıkların ilkinin altında, devletin kendi kurumlarını desteklemeye, güçlendirmeye ve korumaya hizmet eden düzenlemeler bulunmaktadır. Örneğin, devlet tarafından uygulanan vergiler, para cezaları ve harçlar devletin sürekliliği için ihtiyaç duyduğu maddi geliri sağlamaktadır. Bu tür işlemlerin birçoğu ise (hukukun ilk yüzüyle bağlantılı olarak) devletin toplumsal düzeni sağlamaya yönelik işlevini yerine getirmesi veya (devletin farklı amaçlar doğrultusunda hukuk kullanımının üçüncü türü olarak birkaç satır sonra ele alınacak) kamu yararı kavramı ile gerekçelendirilmektedir.

Hukukun devlet tarafından kullanılmasının ikinci başlığı, devlet yapılanmasının ve iç işleyişinin düzenlenebilmesi amacıyla oluşturulmuş; anayasal hükümler, seçim yasaları ve devlet bütçesi gibi kapsamlı kurallar dizisini içermektedir. Üçüncü ve son başlığın altında ise devletin toplumsal arenada bazı girişimler başlatarak belirlediği hedeflere ulaşma amacına hizmet eden düzenlemeler bulunmaktadır. Devletin bu tür girişimleri genellikle kamu yararı ve ortak iyi kavramları altında haklılaştırılmakta ve bu girişimlerin hedeflerine ulaşması amacına yönelik düzenlemeler, uyuşturucuyu ve pornografiyi suç haline getirme, istihdam koşullarını belirleme, sosyal refah sistemi kurma, güvenlik yönetmelikleri çıkartma, ulaşım, iletişim, elektrik, su, kanalizasyon altyapılarını geliştirme, çevreyi koruma gibi geniş bir yelpazeye yayılmaktadır. Bununla beraber devletin hukuku kullanım alanlarına ilişkin ilk etapta ele alınan vergiler (örneğin, araba ya da sigara kullanımını azaltmak amacıyla yakıt ve sigaraya yüksek vergiler getirilmesi) bu kapsamda başvurulan en yaygın yöntemlerden biri olarak karşımıza çıkmaktadır.

Buradan hareketle, hukukun temel işlevi olarak görülen toplumsal düzenin sağlanmasına yönelik kuralların ve hukukun devlet tarafından söz konusu kullanım yollarının birbirleriyle iç içe geçmiş ve etkileşim içerisinde oldukları söylenebilmektedir. 
Ayrıca hukukun iki yüzüne ilişkin belirtilmesi gereken diğer nokta, bunların kronolojik bir sıra izledikleri hususudur. Şöyle ki toplumsal düzeni sağlamaya ilişkin temel kurallar en eski insan topluluklarına kadar uzanmakta; ancak hukukun -zaman içerisinde yaşadığı değişim ve gelişim doğrultusunda ortaya çıkan- ikinci yüzünü oluşturan kurallar, toplumların nüfuslarının artması ve karmaşık bir hal almaları neticesinde siyasi, hukuki kurumlara ihtiyaç duyulması sonucunda varlık göstermeye başlamaktadır. İşte Tamanaha'ya göre, hukuk kavramına ilişkin tanımlamalarda genellikle hukukun geçirmiş olduğu bu evrim göz ardı edilerek, yalnızca ilk ve temel işlevi üzerine odaklanılmakta ve diğer yüzü (içerisinde yer alan üç farklı versiyonu ile beraber) inmal edilmektedir. Nitekim hukuka her iki pencereden yaklaşmak, modern hukuk sisteminin işlevleri açısından daha kapsamlı bir bakış açısı sağlamaktadır ${ }^{86}$.

Son olarak belirtmek gerekir ki hukukun 'iki yüzü' şeklinde bir nitelendirme yapılsa da Tamanaha'nın çalışma boyunca sürekli tekrarlanan "hukukun farklı biçimler ve farklı işlevlerde karşımıza çıkmasının mümkün olduğuna" ilişkin ifadeleri doğrultusunda bu iki yüzün de sınırlı olarak sayılmadığı sonucuna varılabilmektedir. Tamanaha'nın, eserinde hukukun iki boyutundan bahsetmesinin nedeni, devlet hukukunun modern döneme gelene kadar bu yönde bir gelişim izlemiş olmasına dayanmaktadır. Ancak hukukun, sürekli yapım aşamasında olduğu hatırlandığında ileride değişik türlerde, diğer deyişle bu iki boyutu da aşabilecek nitelikte farklı amaçlara yönelik düzenlemelerle karşımıza çıkması da mümkün görünmektedir.

Böylelikle Tamanaha'nın, yukarıda ele alınan itirazları düşünüldüğünde, başarısız oldukları farklı yönleri ortaya koymaya çalıştığı biçimsel ve işlevsel tanımlamalar ışığında "hukuk nedir?" sorusuna kapsamlı bir cevap geliştirebilmenin mümkün olmadığını ileri sürdüğü anlaşılmaktadır. Bu argümanı ile Tamanaha (özellikle hukuk fakültelerinin henüz ilk yıllarından itibaren "hukuk nedir?" sorusuyla karşılaşarak bu yaygın tanımlardan birini içselleştirmiş olan) okuyuculara, tanımlanmasının ilk etapta kolay olduğu düşünülen hukuk kavramının görünenden çok daha karmaşık bir arka planı bulunduğunu göstererek mevcut tanımların sorgulanmasını ve bu kavram üzerine yeniden düşünülmesini gerekli kılmaktadır. Bu noktada "hukuk nedir?" sorusundan ziyade "hukuk ne değildir?" sorusunu cevaplamış gibi görünen Tamanaha'nın ilk soru karşısında geliştirdiği, yukarıda ipuçları var olan kısa cevabı için ise son başlığa, diğer deyişle bu çalışmanın final bölümüne ilerlenmesi gerekmektedir.

\section{HUKUK...}

Bu başlığın, çalışmanın final bölümünü oluşturduğu düşünüldüğünde -günümüz dizilerinde yer alan çoğu zaman tek cümle ile açıklanabilecek sırrın son bölümde ortaya çıkması geleneğinden hareketle- henüz ilk sayfalardan bu yana gizemini koruyan, Tamanaha'ya göre "hukuk nedir?" sorusunun cevabının kısaca ortaya koyulması vakti gelmektedir.

Bu kapsamda, öncelikle kültürel bir ürün olduğunun altını çizmekte olan Tamanaha'ya göre hukuk, herhangi bir şey olabilmekte; herhangi bir görünümle

86 Tamanaha, Realistic Theory, s.127-132. 
karşımıza çıkabilmekte ve herhangi bir işlevi yerine getirebilmektedir. Bu değişkenliği göz önünde tutulduğunda ise hukukun tek, nesnel bir tanımının yapılması mümkün olmamaktadır. Bu nedenle, hukuka dair kurulabilecek tek cümle şu şekilde ifade edilebilmektedir; "hukuk, toplumsal grupların konvansiyonel olarak 'hukuk' dedikleri şeydir."

Bir hukuk tanımı vermekten ziyade, hukukun tanımlanmasına ilişkin bir harita sunmakta olan bu tanımlamanın altında, hukukun tek bir tanımının yapılamayacağına, diğer deyişle hukukun ne olduğuna ya da işlevlerine yönelik 'baştan belirlenen' kıstaslar eşliğinde belirli bir hukuk tanımının ortaya koyulmasının hatalı olduğuna yönelik düşünceler yatmaktadır. Buna göre eksiksiz, kesin bir hukuk kavramı tasarlama fikri, hukukun temel, tek bir kategoriden oluştuğu yönündeki yanlış bir inanca dayanmaktadır. Tamanaha'ya göre hukuk, evrensel niteliklerden yoksun, kültürel bir yapıdan ibaret olup, teorisyenlerin hukuku kısıtlı, sığ kavramsal kategoriler içerisinde sıkıştırmaya çalışmaları hatalı bir tutumdur. Zira bu tanımlar içerisinde yer alan kriterlerin evrensel bir uygulaması mümkün olmamakta, bu nedenle hukukun doğasını da açıklamakta yetersiz kalmaktadır.

Günümüzde bu tanımlamalar, her ne kadar yaygın olarak devlet hukuku çerçevesinde karşımıza çıkmakta ise de bu hukuk türünün yalnızca birkaç asırdır dünya tarihinde yerini aldığı, geçmişte ve günümüzde farklı niteliklere sahip birçok farklı hukuk türünün var olduğu göz önünde bulundurulmalıdır. Bununla beraber var olan hukuk sistemleri ise toplumla beraber sosyal, kültürel, ekonomik, siyasi, ekolojik ve teknolojik koşullar doğrultusunda daima değişmekte ve gelişmektedir. Bu doğrultuda hukuk devamlı olarak evrim geçirmekte ve daha önceki sayfalardan hatırlanacağı üzere "sürekli yapım aşamasında" iken nihai bir açıklama yapmak mümkün olmamaktadır. Bu nedenle hukukun evrensel bir tanımı peşinde koşmak ve dar kavramsal kategoriler altına sıkıştırmaya çalışmak yerine teorisyenler örneğin, devlet hukuku, örf adet hukuku, uluslararası hukuk, dini hukuk, doğal hukuk, ilkel hukuk, Roma hukuku vb. hukuk türlerinin ne olduklarını, işlevlerini ve neden 'hukuk' etiketini taşıdıklarını anlamak amacıyla bu fenomenleri detaylı olarak incelemelidir. Belirtmek gerekir ki hukuk türlerinin hepsi 'hukuk' etiketini taşıyor olmalarına rağmen, bunlar tek bir olgunun farklı varyasyonları olmayıp, her biri çok farklı olgulara işaret etmektedir. Bu nedenle -Minos diyaloğunda Sokrates'in peşinde olduğu- (genel anlamda) 'hukuk' diye tek bir kategori bulunmamakta, bunun yerine farklı hukuk türleri (ve olası tanımları) var olmaktadır. Tek bir cümle ile özetlemek gerekirse, hukuk kavramının belirli bir niteliği, içeriği, kısaca bir özü bulunmamaktadır 87 !

Tamanaha'ya göre hukuka ilişkin bu yaklaşım çoğunluk tarafından tuhaf karşılanmakta ve aslında bunun nedeni hukuka yönelik özcü yaklaşımların günümüzde zihinlerimizde güçlü bir etkisinin bulunmasıdır. Okuyucular muhtemelen hukukun daha somut ve belirgin bir şey olması gerektiği şeklinde olumsuz tepkiler gösterebilmektedir. Ancak hukukun her farklı türü kendi içerisinde aslında bu somut ve belirgin özellikleri

87 Brian Tamanaha, "A Non-Essentialist Version of Legal Pluralism," Journal of Law and Society, C.27, S.2, 2000, s.313. 
barındırmaktadır. Bu ayırt edici özellikler ise teorisyenler tarafından değil, toplumsal aktörler tarafından belirlenmektedir ${ }^{88}$.

Hukukun (hukuk türlerinin) ne olduğunu belirleyen; teorisyenler tarafından ileri sürülen soyut açıklamalar ve teorileri çerçevesinde ortaya koydukları hukuk tanımlamaları değildir. Hukuk varlığını, söz konusu teoriler çerçevesinde ileri sürülen tanımlarda yer alan kriterlere uyum sağlamasıyla kazanmamaktadır. Diğer deyişle hukukun varlığı, hukuk tanımlamalarında yer alan ölçütlere bağlı olmayıp, aksine hukuka dair ileri sürülen ölçütlerin varlığı, hukukun konvansiyonel olarak tanınan çeşitli türlerinin varlığına bağıı olmaktadır!

Kısacası Tamanaha'ya göre, hukuk kavramını formüle etmek, hukuku tek bir biçimde ifade etmeye çalışmak işe yaramamakta; bu sınırlı formüller bize yalnızca hukukun belirli bir zaman diliminde belirli bir toplumda geçerli belirli bir hukuk türünü açıklayabilmektedir. O halde, Tamanaha'nın, eksik, kısıtlı, dar kapsamlı ve daha doğru bir ifade ile "hukuk nedir?" sorusunu cevaplamak açısından başarısız olduklarını ileri sürdüğü hukuk tanımlarının ve en önemlisi hukukun belirli bir özünün olmadığı düşüncesi karşısında, Minos diyaloğundaki öğrencinin, yasa (hukuk) nedir? sorusu üzerine "hangi tür yasadan (hukuktan) bahsediyorsun?" şeklindeki cevabını, mevcut dönemde vermek olanaklı ve hatta gerekli görünmektedir. Bu doğrultuda günümüzde, genel anlamda "hukuk nedir?" sorusunu hatalı bularak Minos'taki öğrenci ile paralel cevabı veren bir kişinin, diyalogda geçenin aksine soruyu tam olarak kavrayamadığı değil, konuyu oldukça iyi anladığı söylenebilecektir.

Nihayet eksiksiz, kesin bir hukuk kavramı tasarlama fikrinin ve hukukun kısıtlı, sığ kavramsal kategoriler içerisine sıkıştırılmaya çalışılmasının hatalı bir tutum olduğunu ileri süren Tamanaha'nın görüşlerine, Nietzsche'nin farklı bir kavrama (ceza kavramına) ilişkin kaleme aldığı birkaç satır ile nokta koyulmasının zamanı gelmektedir. Buna göre, “...cezadaki ikinci öğeye, akışkan öğeye, onun 'anlamı'na gelince, kültürün böylesine geç bir durumunda 'ceza' kavramının artık tek anlamı yok, bütün bir 'anlamlar' birleşimine sahip: Genel olarak cezanın önceki tarihi, çok çeşitli amaçlar için kullanılışının tarihi, sonunda öyle bir kristalleşiyor ki, artık çok zor çözülebilir, çok zor çözümlenebilir, özellikle vurgulamak gerektiği gibi, tümüyle tanımlanamaz oluyor. ...Bütün bir sürecin semiyotik olarak bir araya geldiği kavramlar, tanımdan kaçarlar; yalnızca tarihi olmayanlar tanımlanabilir... ${ }^{89 "}$

Buradan hareketle belirtmek gerekir ki hukuk kavramının da "tarihi olmayanlar" grubuna dahil edilmesinin imkânsız oluşu apaçık bir gerçekliktir...

\section{SONUÇ: RAKIBI 'OYUN'A DAHIL ETMEK}

Bu başlık altında, uzunca yol kat edilerek ortaya koyulan Tamanaha'nın hukuk kavramına ilişkin görüşleri doğrultusunda, kısaca kendisinin neden bu çalışmanın

88 Tamanaha, Realistic Theory, s.194-198; Tamanaha, Analytical Map, s.534,535; Tamanaha, General Jurisprudence, s.194,204.

89 Friedrich Nietzsche, Ahlakın Soykütüğü Üstüne, çev: Ahmet İnam, Say Yayınları, İstanbul, 2013, s.95,96. 
kahramanı olduğuna yönelik gerekçeye yer verilerek yazının nihayete erdirilmesi planlanmaktadır.

Hukuk literatürüne göz atıldığında hukuk ve ahlak arasındaki ilişkiyi ön plana çıkartan teorilerin doğal hukuk; hukuk ve devlet arasındaki ilişkiye odaklanan teorilerin ise hukuki pozitivizm şemsiyesi altında ele alınmakta olduğu görülmektedir. Ancak hukuk ve toplum arasında bulunan ilişki üzerine yoğunlaşmakta olan teoriler kendilerine, alt dallarını oluşturacakları genel bir etiket bulamamaktadır. Hatırlanacağı üzere Tamanaha, hukuk teorilerinin söz konusu kayıp kolunun ait olduğu yere koyulması ve boşluğun doldurulması amacıyla eserlerinde toplumsal hukuk teorisi etiketini ileri sürmektedir. Bu doğrultuda, çalışmanın sonuç satırlarına kadar gelen okuyucunun bir önceki cümlenin ardından Tamanaha'nın hukuk teorilerinin kayıp kolunu gün yüzüne çıkartmasına yönelik çabasının altında; ilk etapta taraftarı olduğu (gerçekçi) hukuk teorisini bu akım içerisinde değerlendirmesine ilişkin gerekçenin bulunduğunu düşünmesi muhtemeldir. Ancak bu çalışmada Tamanaha'ya yer verilmesinin nedenine gelindiğinde altta yatan gerekçeler birbirlerinden ayrılmaktadır.

Şöyle ki çalışma ile varılmak istenen sonuç herhangi bir hukuk akımının 'en ideal', 'en kusursuz' ya da 'en doğru' olduğunu ileri sürmekten ziyade, üç hukuk akımının da aynı derecede güçlü/zayıf yönlere ve üçünün de hukukun doğasına ilişkin tartışmalarda eşit öneme sahip oldukları görüşünün aktarılabilmesine yöneliktir. Binlerce yıl öncesinde varlığını koruyan söz konusu üç ana akımın, günümüze yaklaşıldıkça literatürdeki çoğu eserde ikiye düştüğüne ilişkin tespitler hatırlandığında hukukun sacayaklarından birinin yokluğundan bahsedilebilmektedir. Bu kapsamda, hukuk akımlarının üçünün de aynı öneme sahip oldukları görüşünü ortaya koyabilmek için öncelikle (zaman içerisinde ortadan kaybolan) üçüncü akıma ve sonrasında (gün yüzüne çıkartılan) bu üçüncü akımın -literatürde önemli bir ağırlığı bulunan diğer iki akıma- ne denli ciddi bir rakip olduğunu gösterebilmeye ihtiyaç bulunmaktadır.

İşte Tamanaha özellikle hukuki pozitivizm ve doğal hukuk teorileri çerçevesinde ileri sürülen biçimsel ve işlevsel hukuk tanımlamalarının başarısız bir görünüm sergilemekte olduklarını ayrıntılı gerekçeler ile ortaya koyarak, toplumsal hukuk teorilerinin onlara güçlü bir rakip olduğunu hatırlatmaktadır. Diğer deyişle, hukuk kavramına ilişkin farklı sorular soran ya da aynı soruları farklı bakış açıları ile yanıtlayan ve birbirlerinin kör nokta aynaları olarak kabul edilebilecek üç hukuk akımının aynı derecede eleştirilebilir/kabul edilebilir olmalarına rağmen, günümüzde ağırlıklı hukuki pozitivizm ve doğal hukuk arasında sürüp giden tartışmalarda, Tamanaha mühim bir perspektifin göz ardı edildiğini ortaya çıkartmaktadır.

Kısacası, hukuk kavramı hakkında derinlemesine düşünebilmek ya da onu tüm boyutlarıyla kavrayabilmek açısından hukuk akımlarından 'ne yalnızca biriyle ne de bir diğeri olmadan' yola devam edebilmek mümkündür. Bu açıdan Tamanaha'nın eserleri, hak ettiği değeri görmeyen hukukun üçüncü penceresinden diğer iki akıma ciddi eleştiriler sunmak suretiyle hukuk kavramını yeniden sorgulatarak, kenarda kalmış bu güçlü rakibi oyuna dahil etmek açısından önemli ve güncel bir kaynak olma niteliği taşımaktadır. 


\section{KAYNAKÇA}

Berman, Harold, The Nature and Functions of Law, Brooklyn, Foundation Press, 1958.

Berman, Harold, "The Historical Foundation of Law," Emory Law Journal, C:54, 2005, ss.13-24.

Bix, Brian, Jurisprudence: Theory and Context, Durham, Carolina Academic Press, 2012.

Bix, Brian, “A New Historical Jurisprudence?" Washington University Law Review, C:95, 2018, ss.1035-1047.

Cairns, Huntington, "What Is Law?" Washington and Lee Law Review, C:27, S:2, 2018, ss.193-222.

Chirayath L., / Sage, Caroline / Woolcock, Michael, "Customary Law and Policy Reform: Engaging with the Plurality of Justice Systems," Washington, DC, World Bank, 2005.

Chroust, Anton Hermann, "Anonymous Treatise on Law: The Pseudo-Platonic Dialogue Minos," Notre Dame Law Review, C:23, 1947, ss.47-53.

Cobb, William, "Plato's Minos," Ancient Philosophy, C:8 S:2, 1988, ss.187-207.

Finnis, John, Natural Law and Natural Rights, Oxford, Oxford University Press, 2011.

Fuller, Lon, The Morality of Law, New Haven, Yale University Press, 1964.

Gardner, John, Law as a Leap of Faith: Essays on Law in General, Oxford, Oxford University Press, 2012.

Green, Leslie, "The Forces of Law: Duty, Coercion and Power," Ratio Juris, C:29, S:2, 2016, ss.164-181.

Hart, H. L. A. The Concept of Law, Oxford: Clarendon Press, 1961.

Hayek, Friedrich, Law, Legislation and Liberty: Rules and Order, Chicago, University of Chicago Press, 1973.

Himma, Kenneth E., The Nature of Law: Philosophical Issues in Conceptual Jurisprudence and Legal Theory, Brooklyn, Foundation Press, 2011.

Isser, Debbie, Customary Justice and the Rule of Law in War-Torn Societies, Washington, DC, U.S. Institute for Peace Press, 2011.

Lamb, W.R.M., Plato: Charmides, Alcibiades 1 \& 2, Hipparchus, The Lovers, Theages, Minos, Epinomis, Cambridge, Harvard University Press, 1927.

Lee, Kevin P., "Realism and Jurisprudence: A Contemporary Assessment," Golden Gate University Law Review, C:49, S:2, 2019, ss.77-89.

Lewis, Bradley, "Plato's Minos: the Political and Philosophical Context of the Problem of Natural Right," The Review of Metaphysics, C:60, S:1, 2006, ss.17-53.

Lips, Julius E., "Government," General Antropology, (ed.) Franz Boas, New York, D.C. Heath and Company, 1938, ss. 487-534.

Lutz, Mark J., "The Minos and the Socratic Examination of Law," American Journal of Political Science, C:54, S:4, 2010, ss.988-1002. 
Nietzsche, Friedrich, Ahlakın Soykütüğü Üstüne, çev: Ahmet İnam, Say Yayınları, İstanbul, 2013.

Marmor, Andrei, "The Nature of Law," Stanford Encyclopedia of Philosophy, https://plato.stanford.edu/entries/lawphil-nature/

McCusker, Claire, "Between Natural Law and Legal Positivism: Plato's Minos and the Nature of Law," Yale Journal of Law and the Humanities, C:22, S:1, 2010, ss.83-104.

Moore, Sally Falk, Law as Process: An Anthropological Approach, London, Routledge and Kegan Paul 1978.

Oakeshott, Michael, The Concept of a Philosophical Jurisprudence: Essays and Reviews 1926-1951, (ed.) Luke O’Sullivan, Imprint Academic, 2007.

Pangle, Thomas L., The Roots of Political Philosophy: Ten Forgotten Socratic Dialogues, London, Cornell University Press, 1987.

Plato, Laws (Book 1-6), (ed.) R.G. Bury, C:1, Cambridge, Harvard University Press, 1961.

Platon, Minos, (çev.) Hamdi Varoğlu, İstanbul, Sosyal Yayınları, 2001.

Platon, Minos-Epinomis, (çev.) Furkan Akderin, İstanbul, Say Yayınları, 2020.

Pound, Roscoe, "The Scope and Purpose of Sociological Jurisprudence: I. Schools of Jurists and Methods of Jurisprudence," Harvard Law Review, C:24, S:8, 1911, ss.591619.

Raz, Joseph, "Can There Be Theory of Law?" The Blackwell Guide to the Philosophy of Law and Legal Theory, (ed.) Martin P. Golding, William A. Edmundson, Oxford, Blackwell, 2005.

Raz, Joseph, The Authority of Law, Oxford, Oxford University Press, 2009.

Rowe, Christopher, "Cleitophon and Minos," Cambridge History of Greek and Roman Political Thought, (ed.) Christopher Rowe, Malcolm Schofield, Cambridge, Cambridge University Press, 2000, ss.303-309.

Salmond, John, Jurisprudence, London, Sweet and Maxwell Press, 1924.

Shapiro, Scott J., Legality, Cambridge, Harvard University Press, 2011

Solum, Larry, "Legal Theory Lexicon: The Nature of Law," Legal Theory Blog, https://Isolum.typepad.com/legaltheory/2020/06/legal-theory-lexicon-the-nature-oflaw.html

Stein, Peter, "The Tasks of Historical Jurisprudence," The Legal Mind: Essays for Tony Honore, (ed.) Neil MacCormick, Peter Birks, Oxford, Clarendon Press, 1986.

Strauss, Leo, Liberalism Ancient and Modern, University of Chicago Press, London, 1995.

Tamanaha, Brian,

- "A Non-Essentialist Version of Legal Pluralism," Journal of Law and Society, C.27, S.2, 2000, ss.296-321.

- A General Jurisprudence of Law and Society, New York, Oxford University Press, 2001.

- "Understanding Legal Realism," Texas Law Review, C:87, S.4, 2008, ss.731-785. 
- "An Analytical Map of Social Scientific Approaches to the Concept of Law," Legal Theory and the Social Sciences, C: II, (ed.) Maksymilian Del Mar, Michael Giudice, New York, Routledge, 2010, ss.501-535.

- "What is 'General Jurisprudence'? A Critique of Universalistic Claims by Philosophical Concepts of Law," Washington University School of Law, Legal Studies Research Paper Series, No:12-03-02-2012.

- "The Third Pillar of Jurisprudence: Social Legal Theory," William and Mary Law Review, C:56, 2015, ss.2235-2277.

- "Insights about the Nature of Law From History," Kobe Memorial Lecture, Archiv fur Rechts- und Sozialphilosophie, 2017.

- A Realistic Theory of Law, Cambridge, Cambridge University Press, 2017.

- "Sociological Jurisprudence Past and Present", Law \& Social Inquiry, C:45, S:2, 2020.

- A Realistic Theory of Law, This is Not a Pipe Podcast, https://www.tinapp.org/episodes/realistictheoryoflaw (19.12.2020).

Taylor, A. E., Plato: The Man and His Work, New York, Humanities Press, 1952. 